\title{
関東地方におけるフィリピン海・太平洋プレートの 地下境界の微細構造
}

\author{
建設省建築研究所国際地震工学部* 古 川 信 雄 \\ 防災科学技術研究所** 井 元 政二郎
}

\section{Fine Structure of an Underground Boundary between the Philippine Sea and Pacific Plates beneath the Kanto District, Japan}

\author{
Nobuo Hurukawa \\ International Institute of Seismology and Earthquake Engineering, Building Research Institute, \\ Tatehara 1, Tsukuba-shi, Ibaraki-ken 305, Japan \\ and Masajiro Iмото \\ National Research Institute for Earth Science and Disaster Prevention, Tennodai 3-1. \\ Tsukuba-shi, Ibaraki-ken 305, Japan
}

(Received June 8, 1990; Accepted September 12, 1990)

The Philippine Sea plate subducting beneath the Japanese Islands is colliding with the Pacific plate at the depth of 50 to $80 \mathrm{~km}$ beneath southwestern Ibaraki and central Chiba prefectures, the eastern Kanto district. Relocating earthquakes caused by this collision, we investigated focal mechanisms and a fine structure in the source region in detail.

Earthquakes observed by a network of National Research Institute for Earth Science and Disaster Prevention are relocated by the Joint Hypocenter Determination (JHD) method. The JHD method was extended by using a following constraint: A station correction is independent of both a distance and an azimuth from a center of a studied region to a station. This prior information makes results by the JHD method stable.

Almost all earthquakes in this region are thrust events of which nodal planes dip westward at a low angle. They occurred inside a boundary layer with a thickness of about $4 \mathrm{~km}$ dipping westward at an angle of about $30^{\circ}$, that is a boundary of the subducted two plates. Stress state and a seismic velocity in the boundary layer imply an origin of the layer is a subducted oceanic crust in the Pacific plate. Its size is about $90 \mathrm{~km}$ in the NS direction and $7-16 \mathrm{~km}$ in the EW direction. It inclines westward at an angle of about $25^{\circ}$ in the northern part, and inclines west-southwest at an angle of about $30^{\circ}$ in the southern part. Although all events inside the boundary layer are thrust type of which nodal planes are parallel with this layer, many of them may have occurred along planes which are parallel to nodal planes dipping eastward at a high angle.

However, a magnitude 6.1 earthquake with a vertical fault plane of which east side subsided occurred inside the Pacific plate in Oct. 1985. This event implies coupling of the two plates above it is stronger than that of the surrounding region. Furthermore, a few earthquakes occurring at the western edge of the boundary layer show normal faulting with the NE-SW or ENE-WSW tension axes, which are supposed to be caused by stress concentration at the ends of the boundary layer mentioned above. Therefore these two kinds of exceptional events define the boundary between strong-and weak-coupling areas of the two plates very well.

K£y words: Joint hypocenter determination, Southwestern Ibaraki earthquakes, Central Chiba earthquakes, Plate boundary, Seismic coupling. 


\section{§1.はじめに}

関東地方は日本列島で最も地震活動の高い地域の一つ であり,とりわけ, 茨城県南西部から千葉県中部にかけ ての地域では深さ 40 80 km の地震が定常的に頻発し ている. 地震活動は 1980 年代になってから特に活発に なり，1980 年 9 月 25 日にマグニチュードM6.1の千葉 県中部地震が $\mathrm{M} 6$ 級の地震としては 24 年ぶりに発生し た。 その後, 1983 年 2 月 27 日の茨城県南部地震 $(M$ $6.0), 1985$ 年 10 月 4 日の茨城千葉県境地票 $(M 6.1)$ と $M 6$ 級の地震か続発している。

茨城県南西部の地震は, 西側の震源の深さ $40 \sim 60$ $\mathrm{km}$ のいわゆる鬼怒川側の地震群之, 東側の深さ 60 $80 \mathrm{~km}$ のいわゆる筑波側の地震群にわかれる. 鬼怒川側 地震群はその発震機構が北西方向にスリップ・ベクトル をむつ低角逆断層型であることから，沈み込むフィリピ ン海プレートとその上のユーラシアプレート（あるいは 北アメリカプレート）の境界で発生していると考えられ ている [笠原 (1985), 中村・島崎 (1981)]. 一方, 深さ 60 80 km の筑波側地票群は, 同じ深さに発生する千 葉県中部の地震群とともに，地震の発震機構が西向きの スリップ・ベクトルをすつ低角逆断層型であることか ら、太平洋プレートとフィリピン海プレートの境界で発 生しているとみなされている [笠原 (1985)，中村・島崎 (1981)]. これらの考え方, すなわちフィリピン海プレー トが茨城県南西部鬼怒川側でユーラシアプレートと, 茨 城県南西部筑波側から千葉県中部にかけての地域で太平 洋プレートとカップリングしているというモデルは, フィリピン海プレート内の起震応力場をも説明する [井 元 $(1984,1985)]$. 上記 3 地震のうち前 2 地震はまさに この太平洋・フィリピン海両プレート境界で発生した地 震である [例えば，大竹・笠原 (1983), OKADA and KASAHARA (1990)].ところが, 3 番目の地震はまったく 異なる発震機構解をすち, 太平洋プレート内部で発生し た地震と考えられており [堀 (1986)], 単純な滑り込み だけでは説明できず，多少複雑である．また，地震の震 源は面状というよりも棈円体状にぼんやり分布してお り, 両プレート徨染域のどこで発生しているのか暧昧な 点も残っている. 例えば，逆断層型の地带でもプレート 内部で発生しているという考えもある [MAKI (1984), MAKI et al. (1980), SoMERVILLE (1980)]. また, 千葉県 中部では逆断層型地震だけでなく張力軸が西北西〜東南 東の正断層型地震もみられる [望月・他 (1985)]. 一方, 両プレートの境界に関しては, OBARA (1989) はS 波反 射波を用いて太平洋プレート上面の位置を求めている. それによると, 茨城県南西部から千葉県中部にかけて 屯, 地䠍群の震源とほぼ一致する位置に， $\mathrm{S}$ 波反射面，
すなわちこの地域では両プレートの境界面が存在するこ とが明らかにされている。

本論文では, これら太平洋プレートとフィリピン海プ レートの衝突にともなって発生していると考えられてい る, 茨城県南西部筑波側加ら千葉県中部にかけての地域 に発生する深さ $50 \sim 80 \mathrm{~km}$ の地震の震源を，新たに開 発した改良連係震源決定法を用いて再決定する. それに より, 速度構造の 3 次元的不均質による走時異常は観測 点補正値を用いて補正されるので, 地震の規模や観測点 組み合わせの違いによる震源の系統的誤差はかなり除去 でき, 震源精度は大幅に向上する. そのうえで, 主な地 震の発震機構を調へ, 地震の空間分布と発票機構から, 太平洋プレートとフィリピン海プレート衙乫域の構造と 地震発生様式, 両プレートのカップリング状況等を詳し く調べる.

なお今後,これらの地震活動帯を, その主要活動域で ある茨城県つくば市と千葉県千葉市にちなんで,「筑 波・千葉地震帯」と呼ぶことにする.

\section{§ 2. 改良連係震源決定法}

震源再決定には，震源の相対位置精度を向上させるた めに, 多数の地震の震源を観測点補正値とともに同時に 計算する連係震源決定法 (Joint Hypocenter Determination Method) [Douglas (1967), Freedman (1967)] を用いる. しかし，通常の連係縟源決定法では，主に速 度構造の不均質のために観測点配置が悪いときには，震 源が系統的に大きくずれる．そこで，ここでは観測点補 正值 $(S)$ は震央域の中心から測った震央距離 $(D)$ および 観測点方位 $(\theta)$ とは相関がないという2つの拘束条件を 用いて，震源決定の安定化をはかった，すなわち

$$
\begin{aligned}
& \Sigma S_{i} \cdot D_{i}=0 \\
& \Sigma S_{i} \cdot \cos \theta_{i}=0
\end{aligned}
$$$$
\Sigma S_{i} \cdot \sin \theta_{i}=0 .
$$

ここで, $\Sigma$ は $i=1, \ldots, n$ の和を表し, $n$ は観測点数であ る.この改良により, 連係震源決定法の本来の目的の一 つである絶対震源の決定は多少儀性になるが, 観測点配 置が悪い時や，震源が深い時です震源を安定に精度よく 求めることができるようになる。この改良連係震源決定 法 (Modified Joint Hypocenter Determination Method) は結果的には, 基準の地震との走時差を使って 他の地震の票源を計算するマスターイベント法 [DEWEY (1972)] に近い結果を得る方法になるが，後者と比へる とマスターイベントを選ばなくて良いという利点があ る.とりわけ，全観測点で精度よく記録された地票がな い場合には非常に有効である。 


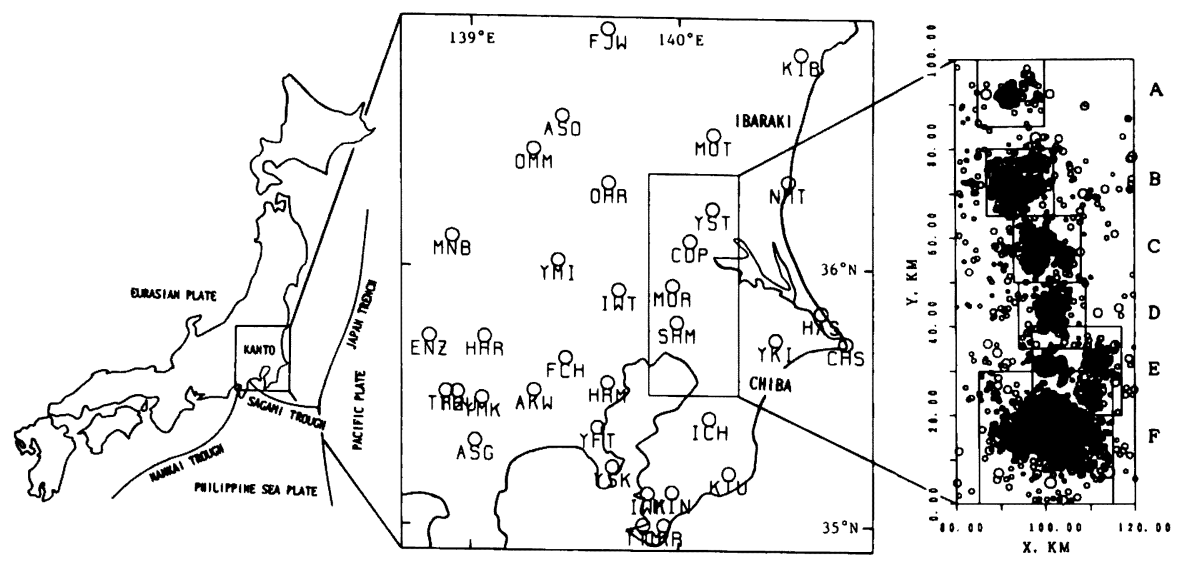

Fig. 1. Observational stations of the NRIESDP (National Research Institute for Earth Science and Disaster Prevention) used in analyses, and a blowup of epicentral distribution of earthquakes in the southwestern Ibaraki and the central Chiba prefectures whose focal depths are $55-75 \mathrm{~km}$ determined by the NRIESDP. Six areas denoted by squares A, B, .., F represent division of epicentral regions of earthquakes relocated in this study. The origin of coordinate $(x, y)$ is located at $\left(139.0^{\circ} \mathrm{E}, 35.5^{\circ} \mathrm{N}\right)$.

Table 1. Initial $\mathrm{P}$ velocity model.

\begin{tabular}{cccc}
\hline $\begin{array}{c}\text { Layer } \\
\text { number }\end{array}$ & $\begin{array}{c}\text { Velocity } \\
(\mathbf{k m} / \mathrm{s})\end{array}$ & $\begin{array}{c}\text { Thickness } \\
(\mathbf{k m})\end{array}$ & $\begin{array}{c}\text { Depth to } \\
\text { layer top }(\mathbf{k m})\end{array}$ \\
\hline 1 & 5.5 & 4.0 & 0.0 \\
2 & 6.0 & 16.0 & 4.0 \\
3 & 6.6 & 10.0 & 20.0 \\
4 & 7.8 & $\infty$ & 30.0 \\
\hline
\end{tabular}

\section{§3. 料}

防災科学技術研究所（旧名：国立防災科学技術セン 夕ー) 関東東海地域地震観測網 [浜田・他 (1982)] にお いて，6点以上の観測点を用いて震源決定された地震の うち，筑波・千葉地祳帯に発生した深さ $50 \sim 80 \mathrm{~km}$ の 地票を解析する。期間は 1983 年 1 月から 1989 年 5 月 である. Fig. 1 に, ルーチン震源の震央分布（深さ 55〜 $75 \mathrm{~km}$ の範囲の地縟のみ）と使用観測点を示す．再決定 に用いた観測点は解析領域の中心から $120 \mathrm{~km}$ 以内で 比較的多数の地震を観測している 34 点である．解析に は珫取ランク A（精度 0.1 秒以内）の $\mathrm{P}$ 波初動のみを用 い，読取観測点数 6 以上の地震の票源を決定する．震源 決定には HuRUKawa and Iмото (1987) が用いた P 波 速度構造を仮定した. Table 1 に示す。

広い地域の地震を同時に改良連係票源決定法で再決定 すると，構造の不均一性のために観測点補正値が震源位 置により異なるので，震源精度が非常に悪くなる，そこ で，ここでは筑波・千葉地震帯の活動を北から順に堀 (1986) と同様に Fig. 1 の四角で示す 6 地域に分け，各
地域每に震源を再決定する．各地域の範囲は以下に示す 立方体の領域である.なお， $(x, y)$ 座標の原点は $\left(139.0^{\circ}\right.$ $\left.\mathrm{E}, 35.5^{\circ} \mathrm{N}\right)$ である.

A. 下 館

$85 \leqq x \leqq 100 \mathrm{~km}, 85 \leqq y \leqq 100 \mathrm{~km}, 63 \leqq z \leqq 78 \mathrm{~km}$

B. 筑 波

$87 \leqq x \leqq 102 \mathrm{~km}, 65 \leqq y \leqq 80 \mathrm{~km}, 58 \leqq z \leqq 73 \mathrm{~km}$

C. 谷田部

$93 \leqq x \leqq 108 \mathrm{~km}, 50 \leqq y \leqq 65 \mathrm{~km}, 55 \leqq z \leqq 70 \mathrm{~km}$

D. 取 手

$94 \leqq x \leqq 109 \mathrm{~km}, 35 \leqq y \leqq 50 \mathrm{~km}, 62 \leqq z \leqq 77 \mathrm{~km}$

E. 八千代

$97 \leqq x \leqq 117 \mathrm{~km}, 20 \leqq y \leqq 40 \mathrm{~km}, 55 \leqq z \leqq 75 \mathrm{~km}$

F. 千葉

$85 \leqq x \leqq 115 \mathrm{~km}, \quad 0 \leqq y \leqq 30 \mathrm{~km}, \quad 50 \leqq z \leqq 80 \mathrm{~km}$

票源決定においては，走時残差が 0.3 秒以上のデータ は逐次取り除き，最終的に各地震の走時残差の標準偏差 が 0.1 秒以下の地震のみを用いる．また，上記範囲外に 再決定された地票は除いた。 ただし，震源全体が移動し たときは範囲を変更した。なお，読取地震数 2 以上の観 測点のみを用いたので，観測点数は地域毎に異なる。

発磦機構の決定においては, 票源よりも深い速度構造 を考虑しなくてもよいように、震央距離 $200 \mathrm{~km}$ 以内の 観測点の $\mathrm{P}$ 波初動極性を用いた。 なお，水平に近く射出 したと思われる震央距離 $150 \mathrm{~km}$ 以上の観測点のデー 夕は半径 0.95 の位置に示し, 初動極性の報告のない観 測点は×印で示した。そして,これらのデー夕は参考に 
a) RELOCATED
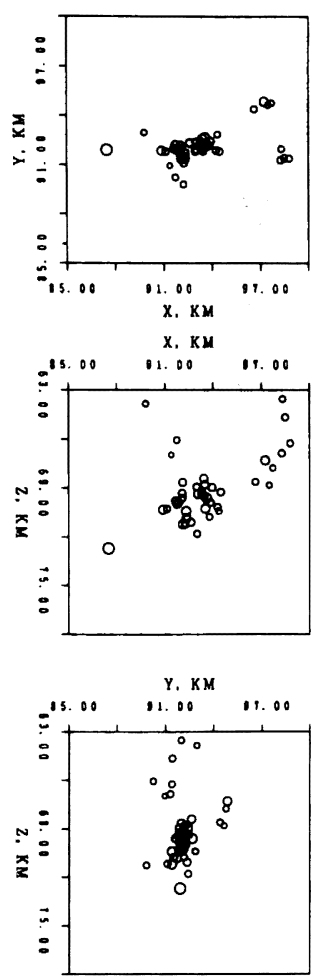

b) ROUTINE

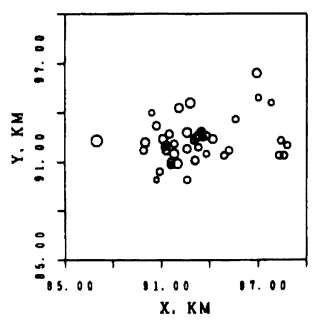

$x, K M$
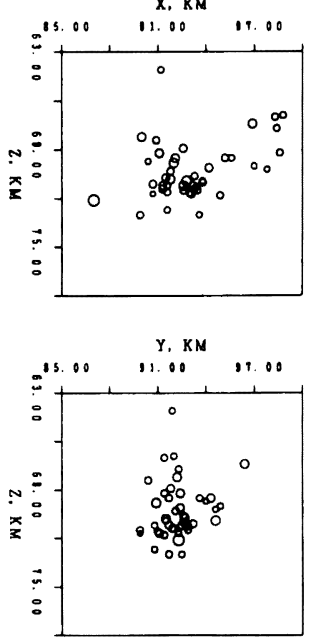

Fig. 2. Comparison of hypocentral distribution in the region A (Shimodate). a) Relocated hypocenters in this study. b) Original hy. pocenters routinely determined by the NRIESDP. Upper: Epicentral distribution. Middle: Depth distribution along East-West cross section. Lower: Depth distribution along North-South cross section. A radius of a circle is proportional to magnitude.

用いた，以下の図において，発震機構の投影はすへてて下 半球等積投影である. 発震機構を求めたのは各地域再決 定地震の 1 割強であるが, 地票数が多いF. 千葉地域に ついては $M 4.0$ 以上の地震に限った。

\section{§4. 結 果}

A. 下館

観測点数は 24 , 地震数は 44 個である. Fig. 2 に，再 決定震源と, 再決定された地磦のルーチン震源を示す. 再決定により震源はより㹟い場所に集中し, 精度の向上 か認められる. 特に, 深さと南北方向の改善が著しい. 再決定震源座標 $x, y, z$ の標準誤差のそれぞれの平均値 は, $0.40,0.36,1.06 \mathrm{~km}$ である. 大多数の地震は東から 西へ約 $30^{\circ}$ の角度で傾斜する面上で発生しており, 地磦

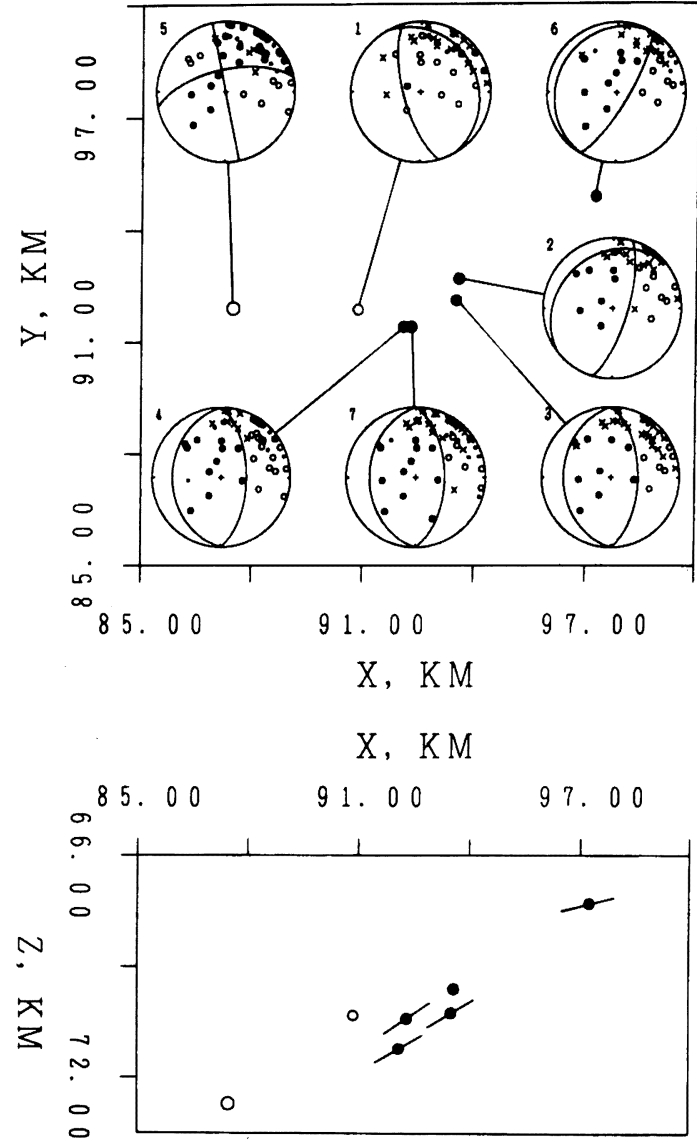

Fig. 3. Focal mechanisms of earthquakes with magnitude greater than or equal to 3.5 in the region A (Shimodate). Equal-area projection of the lower hemisphere of the focal sphere. Large open and solid circles in focal spheres represent clear dilatational and compressional first motions, respectively. Less reliable first motions are shown by small circles. Crosses indicate unknown arrivals. Hypocentral distribution of relocated earthquakes along $\mathrm{EW}$ cross section are also shown by circles. Solid circles represent thrust earthquakes of which nodal planes dip westward at a low angle. Inclined lines in EW cross section show nodal planes of such events.

帯の厚さは $2 \sim 3 \mathrm{~km}$ である.

次に, $M 3.5$ 以上の地震 7 個の発震機構を求めた。震 源分布とともに Fig. 3 に示す.これらの地震の票源座標 $x, y, z$ の標準誤差のそれぞれの平均值は，0.21，0.29, $0.73 \mathrm{~km}$ であり, 大きい地㫳は小さい地䟴に比べると更 
a) RELOCATED
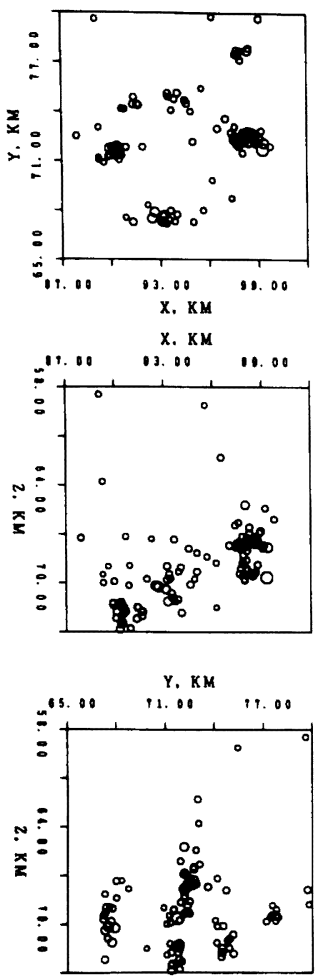

Fig. 4. Comparison of hypocentral distributions in the region $B$ (Tsukuba).

に震源精度がよいことがわかる，なお，他地域について あ震源精度は同程度である， 7 個中，黒丸で示す東側の 5 個は西下がりの低角節面をもつ逆断層型地震であり, 地震帯の厚さは $1 \mathrm{~km}$ 以下である。これらの地震につい ては, 低角節面の傾斜方向が南西から北西方向 $\left(225^{\circ} \sim\right.$ $315^{\circ}$ の範囲）である節面の傾斜角を Fig. 3 の東西断面 図に実線で示した，傾斜角は東西で異なり，平均値は西 で $32^{\circ}$ ，東で $14^{\circ}$ である.これら低角逆断層型地震のス リップ・ベクトルが平均 $279^{\circ} \pm 14^{\circ}$ であり，MINSTER and JORDAN (1979), SENO (1977) のプレートモデルに基 ついて計算した茨城県南西部 $\left(36.0^{\circ} \mathrm{N}, 140.0^{\circ} \mathrm{E}\right)$ におけ るフィリピン海プレートと太平洋プレートの相対運動の 方向, $269^{\circ}$ ないし $273^{\circ}$ [中村・島崎 (1981)] に一致し, かつ西下がりで低角の節面が地震活動面および太平洋プ レートにほぼ平行であることからこれらはフィリピン 海プレートと太平洋プレートの境界で発生した地震と思 われる. なお, Minster et al. (1974), MINSTER and JORDAN (1978) による同地点での太平洋プレートとユー

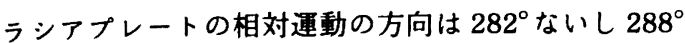
[中村・島崎 (1981)] であり, 上記フィリピン海プレー

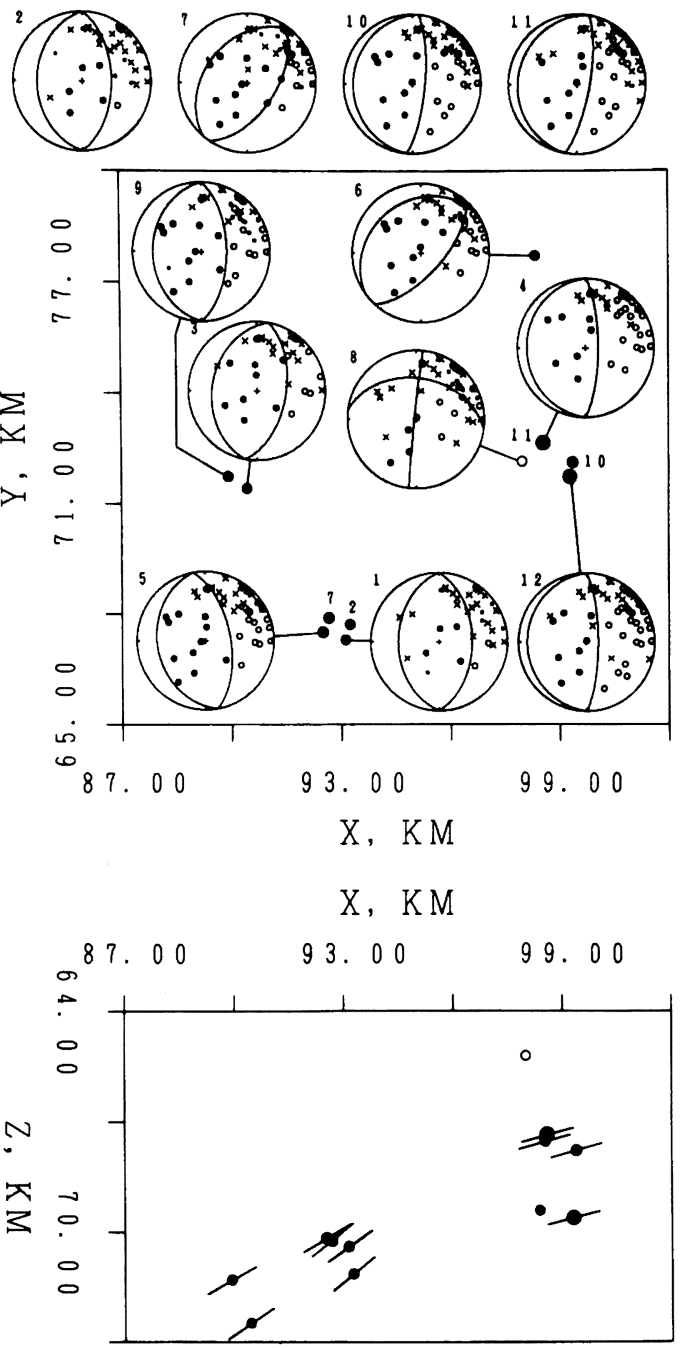

Fig. 5. Focal mechanisms and hypocentral distribution of earthquakes with magnitude greater than or equal to 3.3 in the region B (Tsukuba).

トと太平洋プレートの相対運動の方向との差はわずか $14^{\circ}$ 程度である。一般に, スリップ・ベクトル (高角節面 の走行に直交）の決定誤差はこの差よりも大きいので， スリップ・ベクトルだけから上盤側プレートを特定する ことはできない，しかし，決定精度の良い地震（たとえ ば Nos. 3, 4, 7) のスリップ・ベクトルが $270^{\circ}$ であるこ とと, 太平洋プレートとユーラシアプレートとの間に フィリッピン海プレートの沈み込みにともなう地震が発 生していること [例えば、石田(1986)] から，これらの 地震はユーラシアプレートではなくフィリピン海プレー トと太平洋プレートとの境界の地震である. 他地域につ 

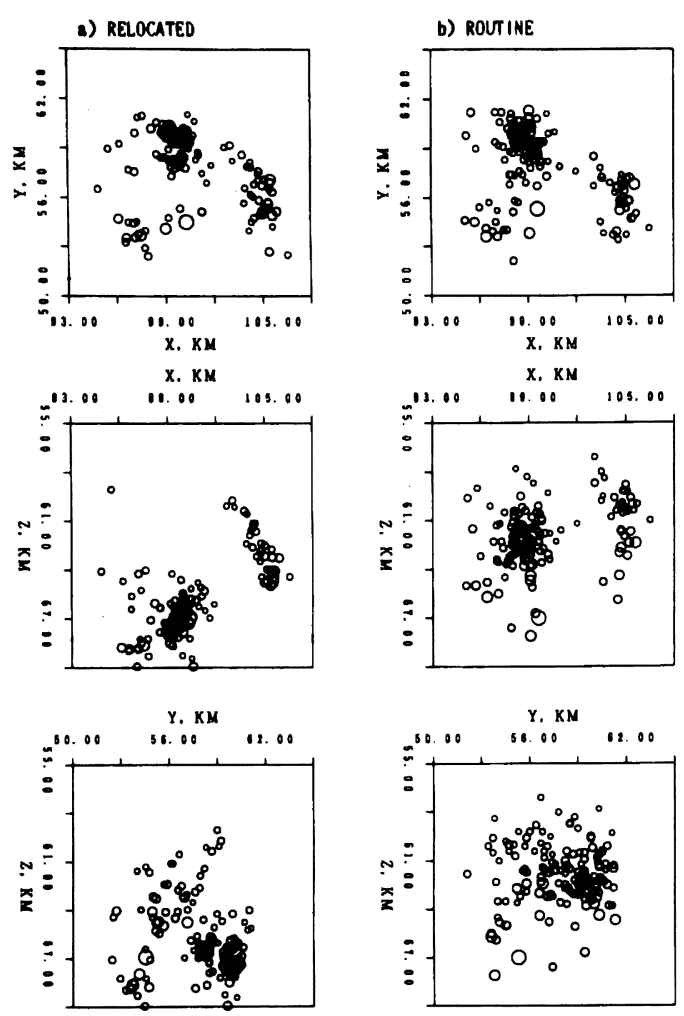

Fig. 6. Comparison of hypocentral distributions in the region $\mathrm{C}$ (Yatabe).

\section{いても同様である.}

一方, 地震密集域の西側の $M 3.5$ の地震 (No. 1) は東 北東〜西南西方向に張力軸をもつ正断首型であり, 震源 は逆断層型地磦発生面の延長よりも少し浅い，更に 3.4 $\mathrm{km}$ 西の本領域西端の地震 (No. 5) は本領域で最大の $M$ 4.5 であり, 北東〜南西張力の横ずれ断層型である.

\section{B. 筑波}

観測点数 26, 地震数 108 個である. Fig. 4 に, 再決定 震源と再決定地震のルーチン震源を示す．下館地域と同 様に大多数の地震は東から西へ約 $25^{\circ}$ の角度で傾斜する 面上にいくつかの塊となって発生している．地震帯の厚 さは約 $3 \mathrm{~km}$ である. このうち $M 3.3$ 以上の 12 個の地 震の発票機構を震源分布とともに Fig. 5 に示す. 地縟面 より数 $\mathrm{km}$ 浅い地震 1 個 (No. 8) 以外はすべて西ないし 北西下がりの低角の節面をもつ逆断層型であり，それら のスリップ・ベクトルが $278^{\circ} \pm 15^{\circ}$ であることから、こ れらは下館地域同様, フィリピン海プレートと太平洋プ レートの境界面で発生した地震と思われる，低角節面の 傾斜角をみると, 東の地震群で約 $15^{\circ}$, 西の地票群で約 $35^{\circ}$ と震源が深くなるほど傾斜が增している，ただし，
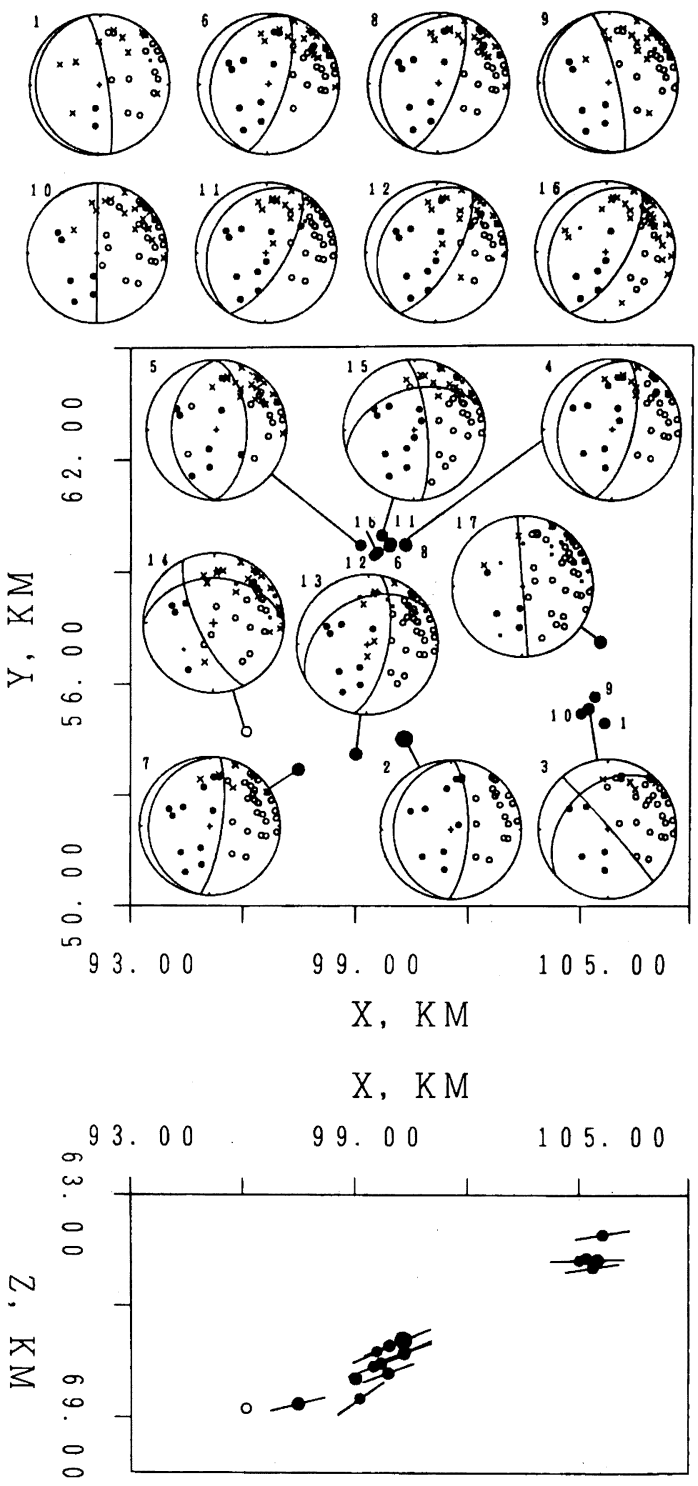

Fig. 7. Focal mechanisms and hypocentral distribution of earthquakes with magnitude greater than or equal to 3.5 in the region C (Yatabe).

地磦の巣毎に詳しくみると, 震源は高角で東下がりの面 上に分布している. Fig .5 に示す地票の深さの標準誤差 は Nos. 1, 2 以外では $0.44 \pm 0.07 \mathrm{~km}$ と非常に精度がよ いことから, 東下がりの節面か断層面である可能性が強 い. 祳源が浅いNo. 8 は発震機構む明らかに他の地縟と 異なり,フィリピン海プレート内部の地震と思われる。

C. 谷田部

観測点数 31, 地震数 148 個である. Fig. 6 に，再決定 

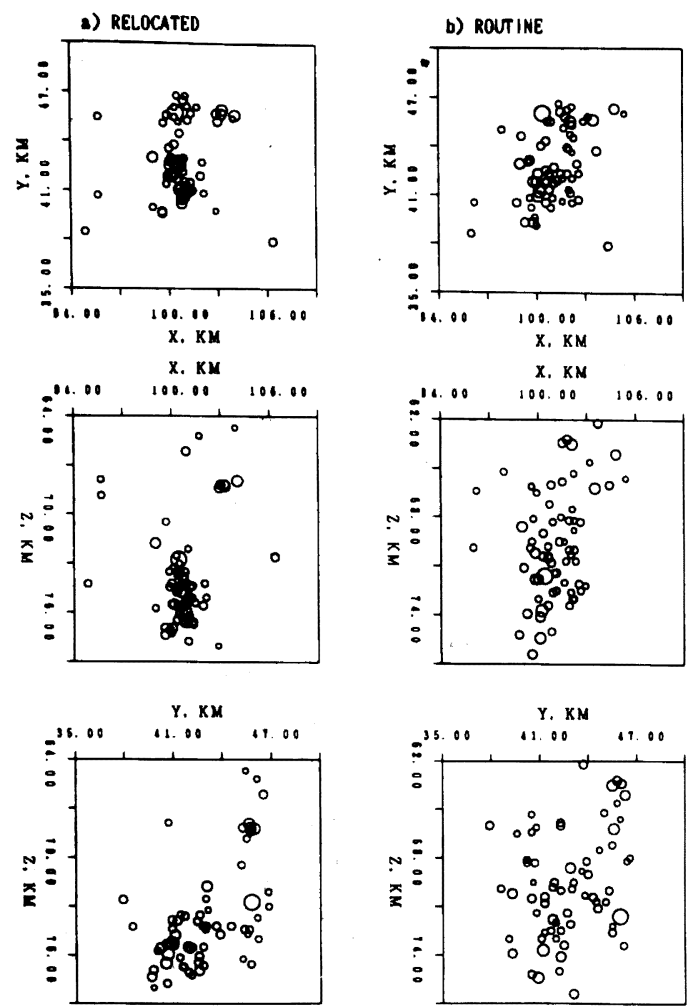

Fig. 8. Comparison of hypocentral distributions in the region $\mathrm{D}$ (Toride).

票源と再決定地震のルーチン震源を示す。下館・筑波地 域之同様に大多数の地震は東から西へ約 $30^{\circ}$ の角度で傾 斜する面上で発生している. Fig. 7 には $M 3.5$ 以上の 17 個の地震の発震機構を震源分布とともに示す．西端の 1 個 (No. 14) 以外はすべて西下がりの低角節面をもつ逆 断層かそれに近い型の地震であり，それらのスリップ・ ベクトルが $275^{\circ} \pm 19^{\circ}$ であることから，これらも上記地 域同様, フィリピン海プレートと太平洋プレートの境界 面で発生したと思われる．地震帯の厚さは約 $1 \mathrm{~km}$ であ る. 次に低角節面の傾斜角をみると, 東で約 $5^{\circ}$, 西で約 $23^{\circ}$ と下館・筑波地域同様，震源が深いほど傾斜が大き い.ただし，こまかくみると，東側の地震群は東下がり の面上に分布しており，高角の東下がりの節面か断層面 である可能性もある. しかし, 1983 年 2 月 27 日の $M$ 6.0 の茨城県南部地票 (No. 2) を含む南西の地震群は, 明 らかに西下がりの低角の面上に分布している.これは, マスターイベント法で余縟の票源再決定をした大竹・笠 原 (1983) の結果とも一致する。，一方，西端の最も深い地 票 (No. 14) は北東〜南西方向に張力軸をもつ正断層型 である.

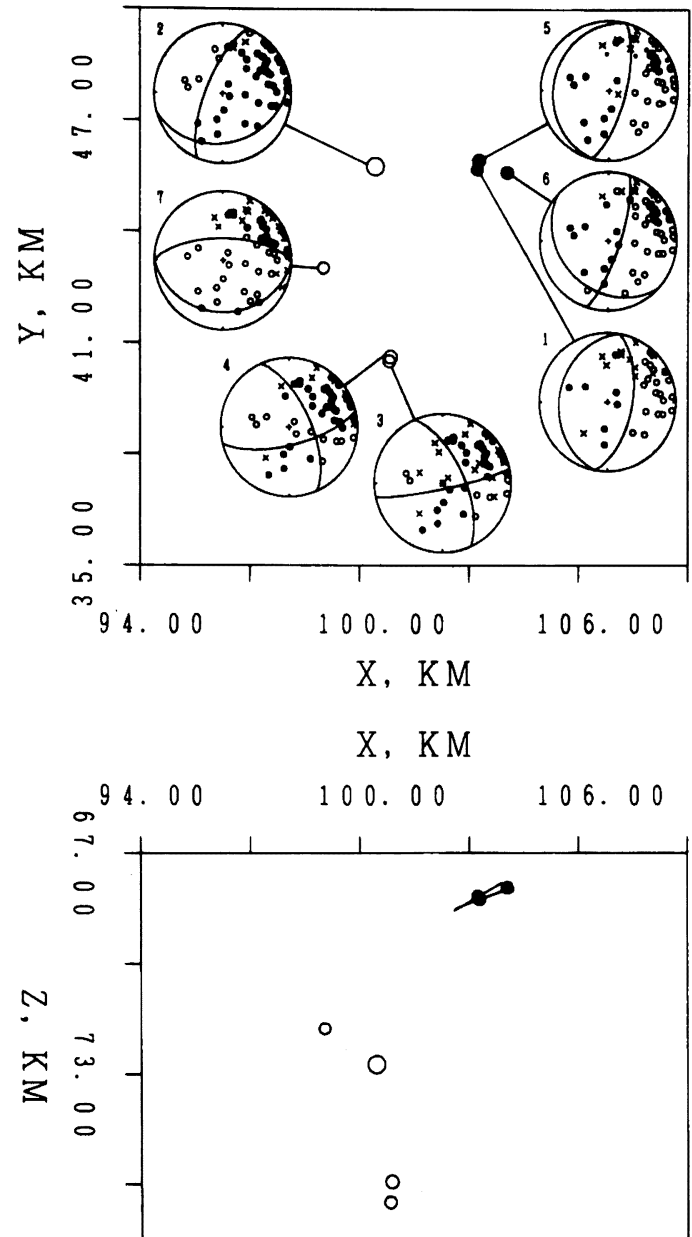

Fig. 9. Focal mechanisms and hypocentral distribution of earthquakes with magnitude greater than or equal to 4.0 in the region D (Toride).

\section{D. 取手}

観測点数 34, 地震数 68 個である. Fig. 8 に，再決定 震源と再決定地票のルーチン震源を示す，再決定震源の 深さの図示範囲は 64 79 km とルーチン震源の範囲よ りも $2 \mathrm{~km}$ 樑くなっている. 下館・筑波・谷田部地域之 は異なり大多数の地震は南北走向鉛直面上に分布し，震 源が少し深い。これらは本地域最大の, 1985 年 10 月 4 日に発生した $M 6.1$ の茨城千葉県境地震の余票群であ る. Fig. 9 には $M 4.0$ 以上の 7 個の地震の発震機構を震 源分布とともに示す．東側の浅い 3 個は西下がりの低角 節面をもつ逆断層型であり，それらのスリップ・ベクト ルが $283^{\circ} \pm 3^{\circ}$ であることから，これらは上記地域同様， フィリピン海プレートと太平洋プレートの境界面で発生 

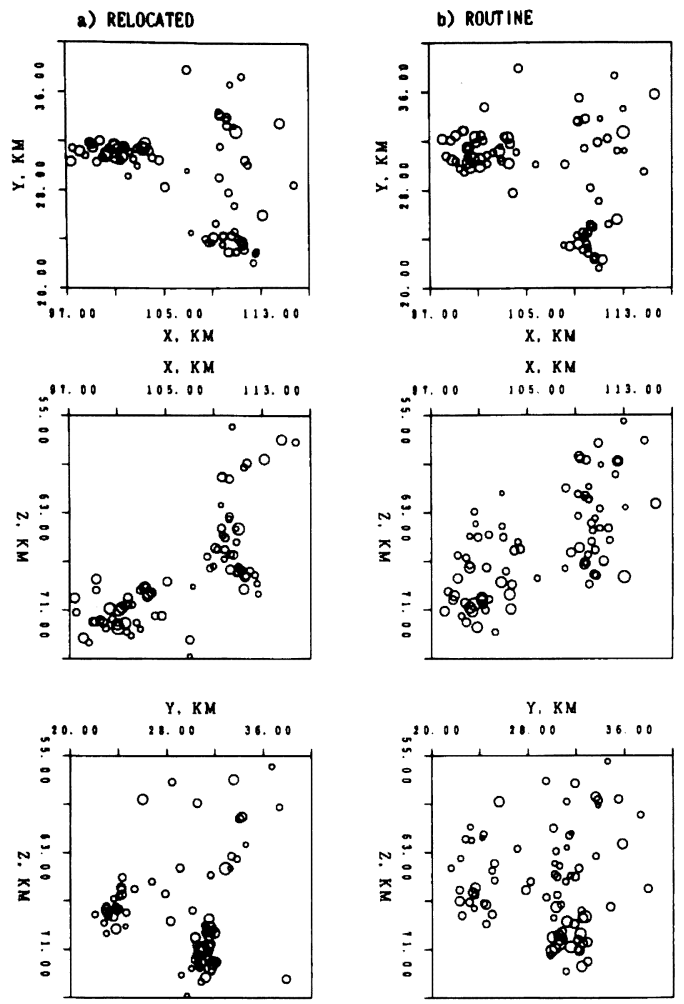

Fig. 10. Comparison of hypocentral distributions in the region $\mathrm{E}$ (Yachiyo).

したと思われるが，他の地震は異なる発震機構を示す．

上記茨城千葉県境地震の余震群は, 両プレートの境界面 で発生する地縟よりも明らかに深く, かつ発震機構が他 の地震のメカニズムとは異なることから,これらは太平 洋プレート内部で発生した地震と思われる. 本地震発生 のメカニズムについては第 6 節で詳しく述べる.

\section{E. 八千代}

観測点数 34, 地震数 81 個である. Fig. 10 に, 再決定 震源と再決定地震のルーチン震源を示す，下館・筑波・ 谷田部地域と同様に大多数の地震は東から西へ約 $30^{\circ}$ の 角度で傾斜する面上で発生している，Fig. 10 の断面図 から, ルーチン震源では再決定票源と比べると, 小さい 地震は浅めに，大きい地票は深めに決定されていたこと が非常によくわかる.これは Table 2 に記すように, 観 測点補正値が-0.6 0.8 秒と大きく，地震の大きさによ り震源決定に使用する観測点数が異なるために震源, 特 に深さが地震の大きさに依存したものである. 他地域に ついても多かれ少なかれこの傾向がある. Fig. 11 には $M 4.0$ 以上の 14 個の地震の発震機構を震源分布図とと もに示す. 地震の深さの標準誤差は $0.60 \pm 0.14 \mathrm{~km}$ であ
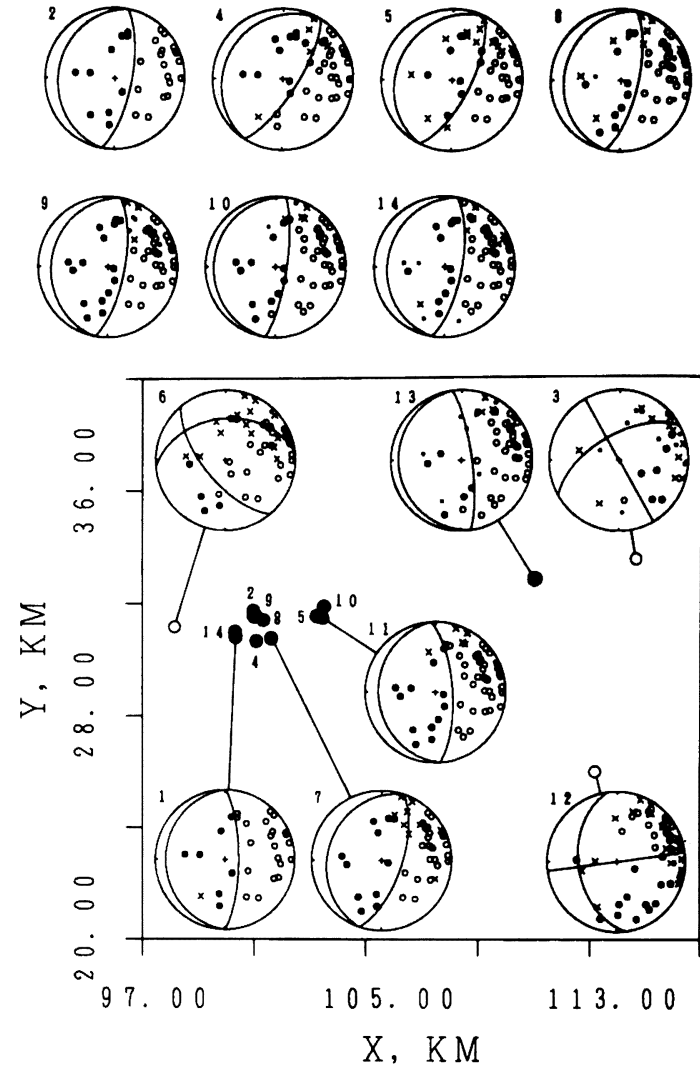

$\mathrm{X}, \mathrm{KM}$

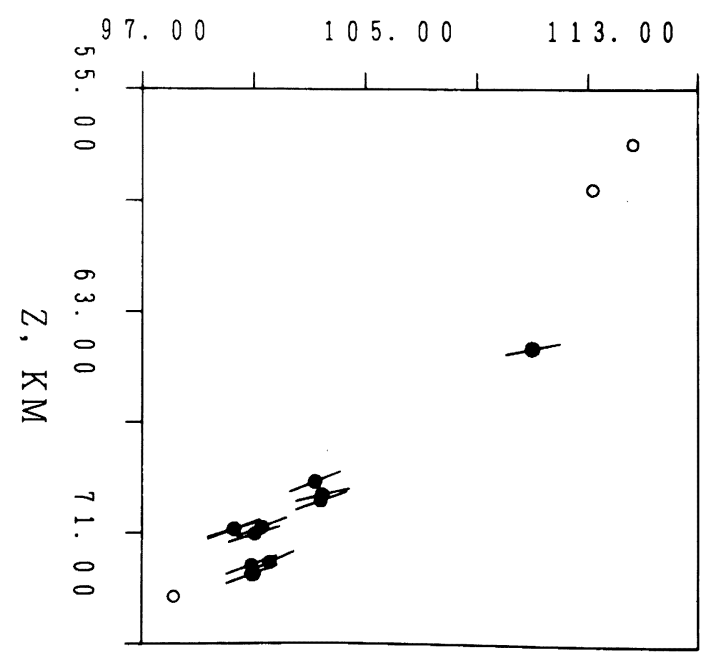

Fig. 11. Focal mechanisms and hypocentral distribution of earthquakes with magnitude greater than or equal to 4.0 in the region $\mathrm{E}$ (Yachiyo). 

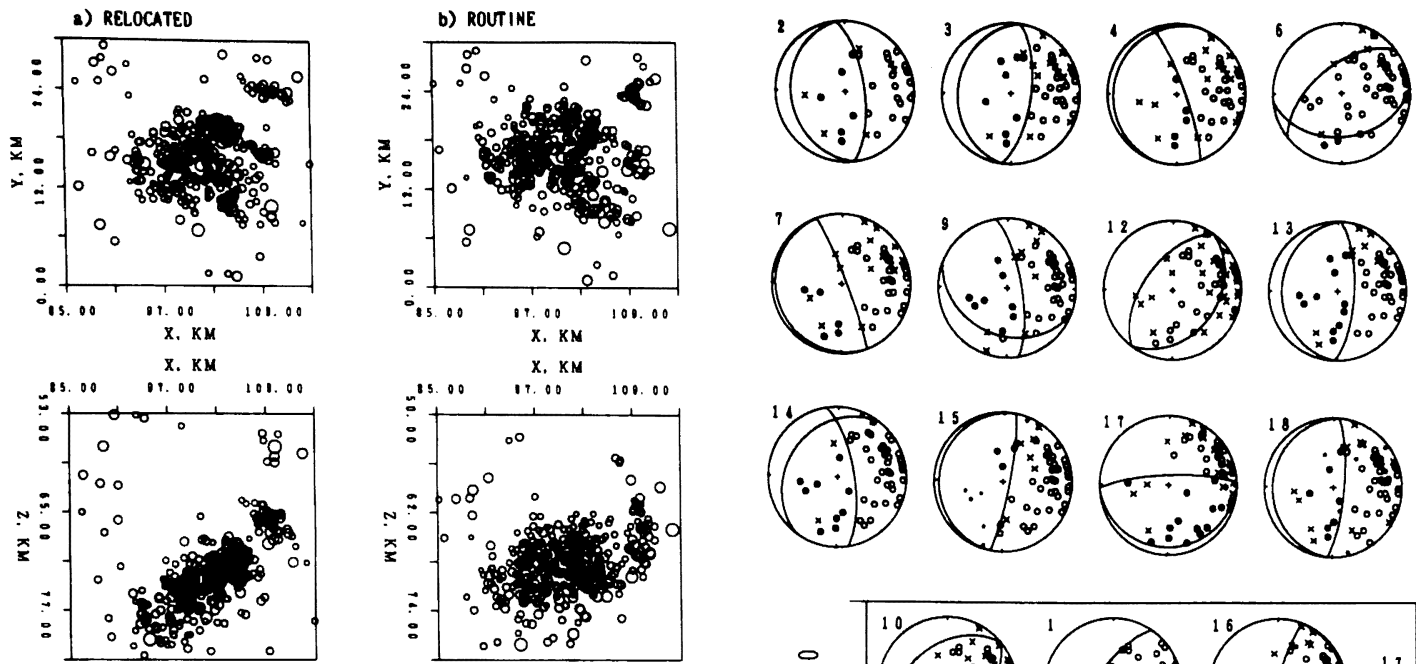

$\mathrm{X}, \mathrm{KM}$
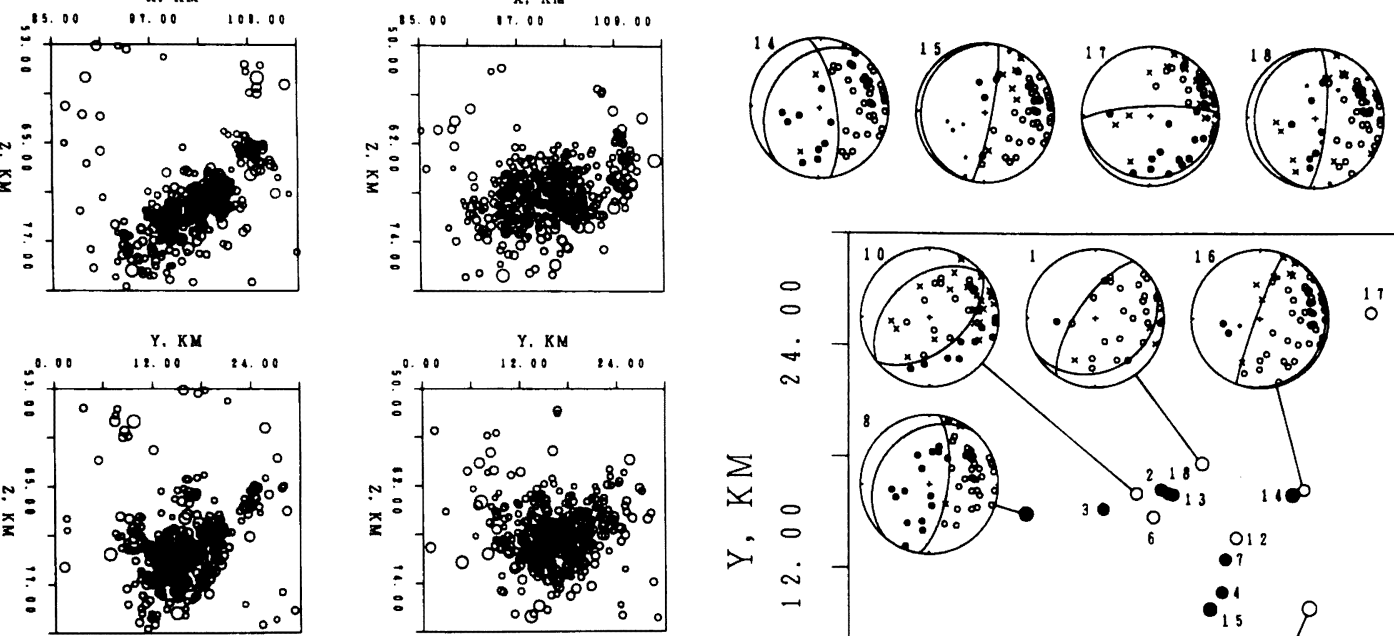

Fig. 12. Comparison of hypocentral distributions in the region $\mathrm{F}$ (Chiba).

\section{る. 東西両端の 3 個以外はすべて西下がりの低角節面を} あつ逆断層型であり，それらのスリップ・ベクトルが $280^{\circ} \pm 12^{\circ}$ であることから,これらも上記地域同様,

フィリピン海プレートと太平洋プレートの境界面で発生 した地震と思われる. 低角節面の傾斜角は, 東で約 $12^{\circ}$, 西で約 $19^{\circ}$ であり, 他地域同様, 西側の深い地震群の傾 斜角のほうが大きい.ただし，西側の 2 つの地震群はそ れぞれ他地域同様東下がりの高角節面が断層面であるか もしれない. 一方, 西端の最も深い地票 (No. 6) は北北東 〜南南西方向に張力軸をもつ正断層型である. 東端の 2 個は他の地震の発生面の延長面上よりあ $5 \mathrm{~km}$ 以上浅 く,太平洋プレート外の地震であると思われる. 発䟴機 構も異なり, 張力軸が東西ないし東南〜北西方向の横ず

Fig. 13. Focal mechanisms and hypocentral distribution of earthquakes with magnitude greater than or equal to 4.0 in the region $F$ (Chiba).

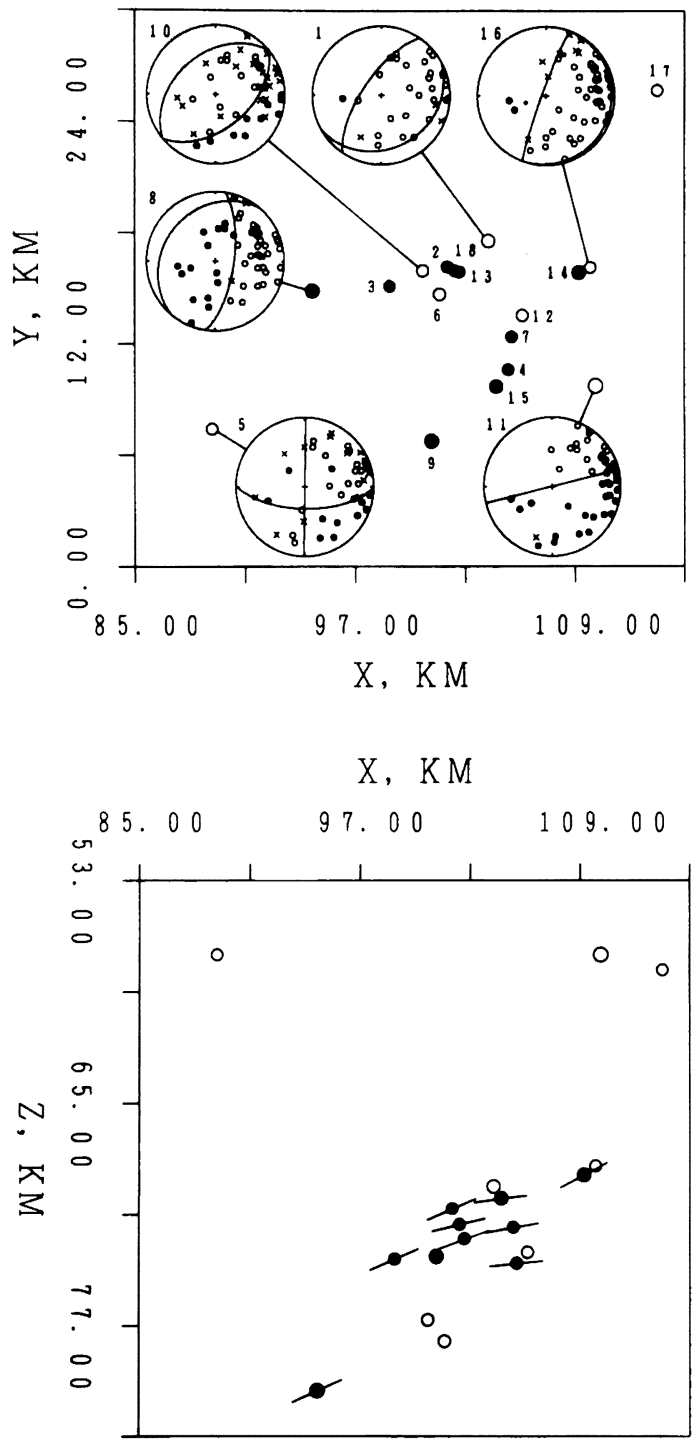


古川信雄・井元政二郎

Table 2. Station Corrections at each region.

\begin{tabular}{|c|c|c|c|c|c|c|c|}
\hline & & A & B & $\mathrm{C}$ & $\mathrm{D}$ & $\mathrm{E}$ & F \\
\hline $\mathrm{AKW}$ & Aikawa & & .265 & .088 & .059 & .147 & .173 \\
\hline ASG & Minamiashigara & -.191 & -.258 & -.343 & -.367 & -.277 & -.256 \\
\hline ASO & Ashio & .079 & .114 & .141 & .177 & .159 & .096 \\
\hline $\mathrm{CDP}$ & NRIESDP & -.025 & -.172 & -.362 & -.570 & -.576 & -.622 \\
\hline CHS & Choshi & .003 & .200 & .316 & .478 & .280 & .201 \\
\hline CKR & Chikura & & & & -.324 & -.272 & -.248 \\
\hline ENZ & Enzan & & .188 & .490 & .624 & .549 & .419 \\
\hline $\mathrm{FCH}$ & Fuchu & .236 & .214 & -.019 & -.238 & -.323 & -.330 \\
\hline FJW & Fujiwara & -.066 & .029 & .084 & .045 & .105 & .060 \\
\hline HAS & Hasaki & -.157 & -.111 & -.053 & .068 & -.122 & .024 \\
\hline HHR & Hinohara & -.099 & .028 & .288 & .283 & .062 & .080 \\
\hline HRM & Kawasaki & & & .450 & .305 & .284 & .190 \\
\hline $\mathrm{ICH}$ & Ichihara & & & .733 & .576 & .474 & .341 \\
\hline IWK & Iwai-kita & & & -.116 & -.028 & .053 & .066 \\
\hline IWT & Iwatsuki & -.713 & -.836 & -.795 & -.583 & -.501 & -.514 \\
\hline KIB & Kitaibaraki & -.082 & -.044 & -.097 & -.066 & .100 & .135 \\
\hline KTU & Katsuura & & & & & -.259 & -.208 \\
\hline MIN & Mineoka & -.133 & -.138 & -.250 & -.099 & -.065 & -.077 \\
\hline MNB & Manba & -.229 & -.157 & -.208 & -.004 & .094 & .363 \\
\hline MOR & Moriya & .333 & .207 & .162 & .123 & .100 & .217 \\
\hline MOT & Motegi & .094 & .087 & .016 & -.063 & .065 & -.036 \\
\hline NMT & Nakaminato & .171 & .054 & -.115 & -.100 & -.093 & -.135 \\
\hline OHR & Ohhira & .202 & .060 & -.079 & -.295 & -.406 & -.437 \\
\hline OMM & Ohmama & -.068 & .038 & .139 & .124 & .196 & .229 \\
\hline SHM & Shimohsa & -.316 & -.331 & -.482 & -.479 & -.511 & -.497 \\
\hline TRU & Tsuru & .151 & .069 & -.046 & -.106 & -.155 & -.175 \\
\hline TR2 & Shishidome & .077 & .013 & -.075 & -.159 & -.208 & -.222 \\
\hline TYM & Tateyama & & & -.082 & -.040 & .065 & .115 \\
\hline YFT & Tomioka & & & & .735 & .785 & .711 \\
\hline YKI & Yohkaichiba & .275 & .400 & .269 & .257 & .248 & .356 \\
\hline YMI & Yoshimi & .053 & -.201 & -.281 & -.150 & .157 & .208 \\
\hline YMK & Yamakita & .242 & .264 & -.026 & -.195 & -.169 & -.190 \\
\hline YSK & Yokosuka & & & .371 & .284 & .332 & .358 \\
\hline YST & Yasato & .163 & .014 & -.120 & -.273 & -.314 & -.394 \\
\hline
\end{tabular}

れ断層型である.

\section{F. 千葉}

これは, 地震活動がもっとも活発な, いわゆる千葉県 中部地震を含む地域である. 観測点数 34 , 地震数 373 個である. Fig. 12 に, 再決定震源と再決定地震のルーチ ン震源を示す． 再決定縟源の深さの図示範囲は 53 83 $\mathrm{km}$ とルーチン震源の範囲よりも $3 \mathrm{~km}$ 深くなってい る. 下館・筑波・谷田部・八千代地域之同様に大多数の 地震は東から西へ約 $40^{\circ}$ の角度で傾斜する面上で発生し ている. Fig. 13 には $M 4.0$ 以上の 18 個の地震の発震機 構を震源分布図とともに示す. 本地域は他地域よりも複 雑である. 東西両端の 3 個の浅い地震以外の多くは西下 がりの低角節面をもつ逆断首型であるが，5個は東西な いし南東〜北西に張力軸を持つ正断層型地磦である.な
お北東の浅い地震 (No. 17) は八千代の南東の地震 (No. 12) 之同一である. この地震の発震機構解は, 南北走向 の節面の傾斜角に任意性があるので，ここでは八千代と は少し変えて示した. 逆断層型の地震は西端の 1 個 (No. 8) を除き，低角節面の傾斜角（平均 $17^{\circ}$ ） と平行な面上 に発生していることと, それらのスリップ・ベクトルが $266^{\circ} \pm 12^{\circ}$ であることから,これらも上記地域同様, フィリピン海プレートと太平洋プレートの境界面で発生 した地震と思われる. しかし，Fig.13において地震群毎 にこまかくみると, Nos. 4, 7,15 と Nos. 2,13,18 (深さ の標準誤差は $0.65 \pm 0.09 \mathrm{~km}$ ）はそれぞれ高角東下がり の面上に分布することから，これらの地震の断層面は東 下がりの節面の可能性が強い. また, No. 16 の正断首型 地縟は，スリップ・ベクトルの方向が他の逆断首型地震 

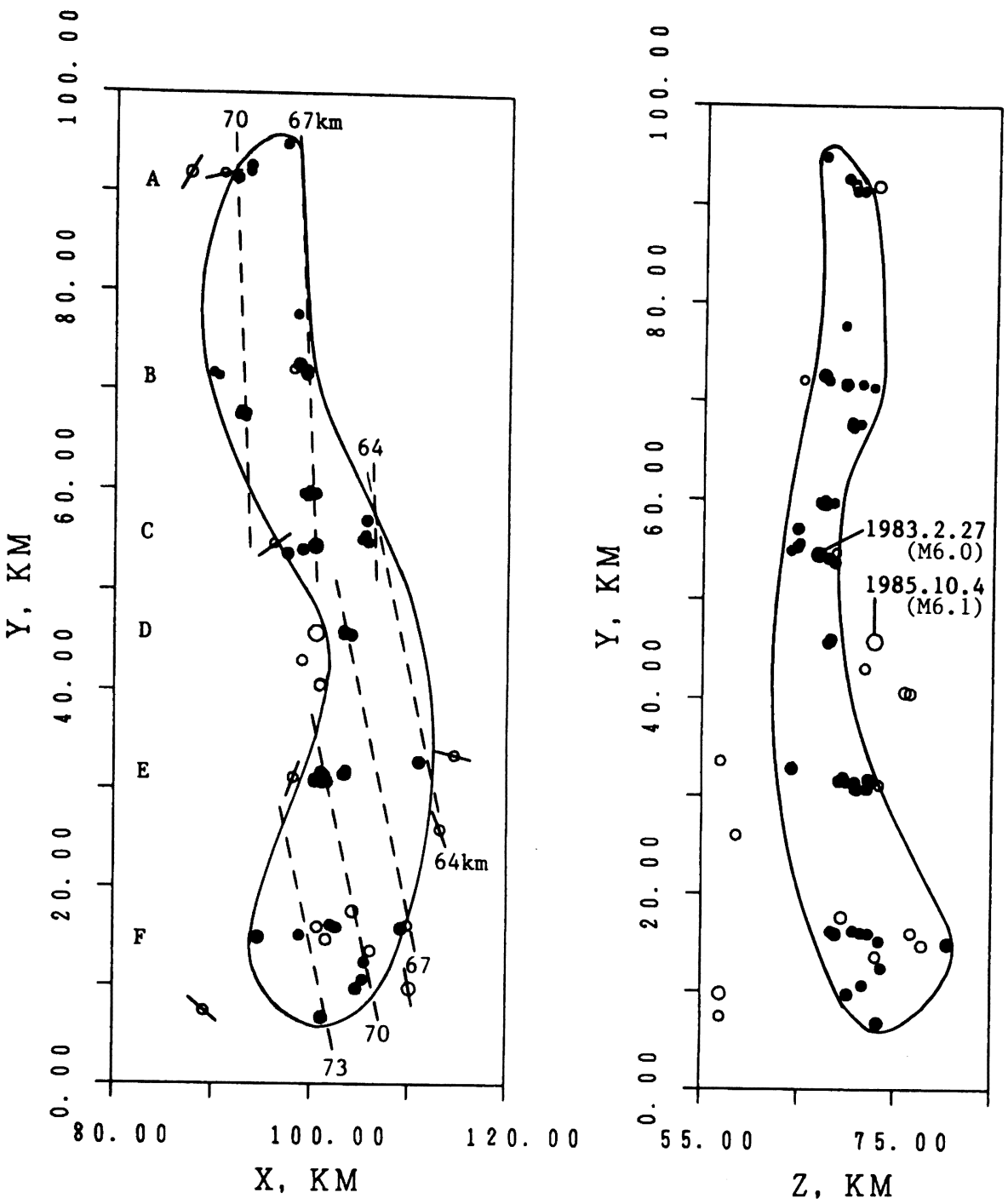

Fig. 14. Hypocenters of relocated earthquakes of which focal mechanisms are obtained. Left: Epicentral distribution. Right: Depth distribution along NS cross section. Thrust earthquakes of which nodal planes dip westward at a low angle are shown by solid circles. Hypocentral areas of these events are enclosed with solid lines. Open circles represent earthquakes with different focal mechanisms. $T$ axes of earthquakes outside the area mentioned above are also shown by solid lines. Iso-depth contour of the upper plane of the Pacific plate is shown by dashed lines.

と同じであることから、ほぼ水平な節面を両プレート境 界と考えることも可能である. そうすればその他 4 個の 正断層型地票の張力軸はすべて北西〜南東にそろうこと になる。これらの地震は, 逆断層型地縟とは票源の深さ が多少異なり，浅い1 個 (No.1)はフィリピン海プレー 卜内部，深い 3 個 (Nos. 6,10，12) は太平洋プレート内 部で発生したと考えられる。.この地域は，Fig. 1 の震央 分布図からあ明らかなように，地震活動があっとも高い
地域であることから、フィリピン海プレートと太平洋プ レートの衝突がもっとも強いために, 両プレート内部で 上下主圧縮応力の正断層型地縟が発生したと考えられ る.

以上，地域毎に結果をみたが，求まった観測点補正値 をまとめて Table 2 に示す. 值は地域毎に大きく变化す ることがわかる，たとえば，震央域にある観測点 CDP では, 0.0 秒から-0.6秒と震央が南へいくにつれて値が 
小さくなっている.このことは逆に，本地域のように構 造の不均質が強い地域での, 震源決定における観測点補 正値の重要性を物語っている. 各観測点毎の平均値をみ ると, 深井戸の FCH, IWT, SHM では $-0.1 〜-0.7$ 秒, 東京湾周辺の厚い堆皘首上の HRM, YFT, ICH では 0.3 $\sim 0.7$ 秒と観測点設置状況や地質構造と整合的である.

\section{§5. 太平洋・フィリピン海プレート間の境界層}

筑波・千葉地震帯の深さ $50 \sim 80 \mathrm{~km}$ の地震は，その 大多数が西下がりの低角節面をもつ逆断層型の発震機構 を示し，この型の地震はすべて東から西へ低角で傾斜す る太平洋・フィリピン海プレート間の境界で発生するこ とが明らかになった，前節ではこれらの地震の発生場所 として, 両プレートの「境界面」という言葉を使ったが, 既に明らかなようにこの「境界面」は少なくとも $2 \mathrm{~km}$ 程度の厚さをもつ層である，それゅえ，以下では両プ レートの「境界層」という言葉を用い，この境界層の性 質を詳しく調べてみる.

\section{1 形状}

Fig. 14 に調査した 6 地域全部において, 発震機構を 決定した地震の震央を示す。西下がり低角節面をむつ逆 断層型地震は黒丸で示し, それらの発生域を実線で囲ん だ.すなわちこの枠内ではフィリピン海プレートと太平 洋プレートの境界層で地震が発生し, 枠外で発生した地 震はすへて違う発震機構の地震である.なお、この外枠 (東西 $40 \mathrm{~km}$, 南北 $100 \mathrm{~km}$ ) の中でも調査していない地 震があるが,ここでは地震が集中発生している調查地域 についてのみ議論している。これら逆断層型地震の震央 をみると，B から C, D, E と少しずつ東側に移動し，D か らは $\mathrm{E}, \mathrm{F}$ と西に広がっている.この地震帯の幅は北端 の A で $7 \mathrm{~km}$, 南端の F で $16 \mathrm{~km}$ である. また, 境界層 の厚さは $1 \sim 4 \mathrm{~km}$, 平均 $2 \mathrm{~km}$ である. ただし、これら の値は発震機構を求めた地震からだしたもので、求めて いない地震はもう少し深さ方向に幅広く分布している。 それゆえ、これらの値は各地域での厚さの下限を意味し ている。

同図には，また境界層上面（これは次項「応力場」の 議論から太平洋プレートとフィリピン海プレートの境界 面と思われる）の深さのコンターを破線で示す、デー夕 数が少ないので,ここでは境界面を, $y=50 \mathrm{~km}$, すなわ ち北緯約 $35.95^{\circ}$ を境に 2 つの平面に分けて示した．北 側ではほぼ真西の $\mathrm{W} 2^{\circ} \mathrm{S}$ 方向に約 $25^{\circ}$ で傾斜し，南側で は $\mathrm{W} 13^{\circ} \mathrm{S}$ 方向に約 $30^{\circ}$ で傾斜する. 走向・傾斜は 1985 年の茨城千葉県境地震 $(M 6.1)$ が発生した D 地域 を境に変化しており,この地震発生と何らかの関係があ るかも知れない.
次に細かくみると，逆断層型地震の発生域は， D 地域 以外では東西 2 つに分かれている，低角節面および境界 層の傾斜角は, 常に東側で小さく $\left(5^{\circ} \sim 17^{\circ}\right)$, 西側で大 きい $\left(19^{\circ} \sim 35^{\circ}\right)$. 東西の傾斜角の差は, $\mathrm{ABC}$ 地域で平 均 $19^{\circ}, \mathrm{EF}$ 地域で平均 $8^{\circ}$ と,これもまた $\mathrm{D}$ を境に変化 している. 太平洋プレートの平均的傾斜角はこの付近で $20^{\circ} \sim 30^{\circ}$ [例えば石田(1986)]なので，これはプレート 衝突による局所的な变化である.このように不均質が強 いことが，地震活動が高いにもかかわらず， $M 7$ を超え る地震がほとんど発生しない理由のひとつである可能性 がある.

\section{2 応力場}

橋本 (1981) は西南日本において, フィリピン海プ レートの沈み込みによって生じる3 次元応力分布を計算 した. 彼は大陸・海洋両プレートの間に境界層（海洋地 殻を想定）をおき，この層の弾性常数の大きさによって, 両プレートがロックされた場合とデカップルされた場合 を考えた. locked model（ヤング率が大きい）の場合, 北西方向主圧縮の逆断層型（北西下がりの節面が低角） の応力場はプレート境界周辺にはどこにも生じないのに 対し, decoupled model（ヤング率が小さい）の場合は, フィリピン海プレートの北西方向への圧縮力が大きいと きに，上記の逆断層型の応力場が境界層内に現れること を明らかにした。この計算結果を太平洋プレートが沈み 込む茨城県南西部から千葉県中部地域にあてはめれば, 東西圧縮軸で，西下がりの低角節面をもつ逆断層型地震 が発生している領域か境界層, すなわち太平洋プレート 最上部の海洋性地款となる.このことはまた，境界層が 存在すれば、プレート境界地震の断層面が太平洋プレー 卜上面に平行である必要はまったくないことも示唆して いる，ただし，低弾性率の境界首の厚さは限られている ので, 高角の節面が断層面となる大地震は発生できな い. SOMERVILLE (1980) は 1956 年 9 月 30 日の $M 6.3$ の千葉県中部地震を解析し, 発震機構は西下がり低角節 面をむつ逆断層型であるが, 余票分布と地震波形合成か ら断層面は東下がりの高角節面であると結論した：デー 夕不足之分解能の悪さから, 西下がりの低角節面か断層 面である可能性むあるあのの, 上に述べた理由から， $M$ 6.3 程度の高角逆断層地震が境界層で発生してもさしつ かえない，一方，大地震はすべて低角の断層面をむつ低 角逆断層地震となり，境界層最上部のフィリピン海プ レートとの境界で発生し, 太平洋プレートは関東地方の 地下に沈み込んでいく.大地震ではないが，C. 谷田部地 域に発生した 1983 年の $M 6.0$ の地震はその一例であ る.

橋本 (1981) の計算結果によれば，低角の節面は境界 


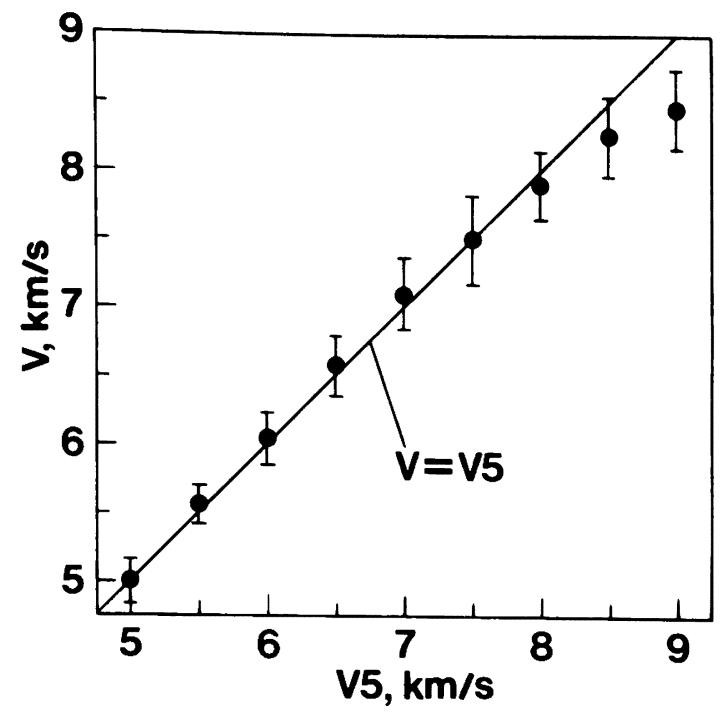

Fig. 15. Calculated velocity $V$ against assumed velocity $V 5$. Bars represent standard deviations. A velocity in the 5th layer where earthquakes occurred was calculated by a method of HuRukawA and Imoto (1987). Fourth layer in Table 1 was divided into two at a depth of $67 \mathrm{~km}$ in this calculation.

層に平行であることが期待される． 5.1 で述べたように 低角節面の傾斜角は場所により変化しているので, 境界 層の形そのものも空間変化していると考えられる. 例え ば, MAKI et al. (1980) と MAKI (1984) は M4 以上の地 震の発震機構を求め, 千葉県中部では逆断層型地震以外 に西側が落ち込む鉛直縦ずれ型地震が多数発生している ことを示したが，今回の解析からも良く似た型の地震は いくつか求まっていることから，これらは低角の節面が ほぼ水平なだけで, 他の多数の地震同様この節面が境界 層に平行な逆断層型地震と思われる. また MAKI et al. (1980) は，これらの地祳の断層面は鉛直の節面と考え て、これらはフィリピン海プレートの北東端の衝突によ り発生した太平洋プレート内部で発生した地震であると 考えた。しかし彼の解析した地震の震源精度等を考慮す れば、これらの地震も境界層内部で発生したと考えるこ ともできる.

第 4 節で述べたように，千葉地域では北西〜南東張力 軸の正断層型地震が，逆断層型地震の発生域の上下で発 生している (Fig. 13). このように震源の深さが少し変わ るだけで応力場が急変することは, 橋本 (1981) の結果 からも明らかなように, 弾性常数の異なる媒質が隣接し ていること, すなわち低弾性常数の境界層が高弾性常数 の媒質の間に存在することと調和的である，逆に，これ
らの地震から, 境界層の厚さを正確に求めることがで き, 千葉地域では約 $4 \mathrm{~km}$ であることがわかる. それゆ え, 今後は境界層の厚さとして, この值を用いることに する。なお，この種の正断層型地震が逆断層型地震と同 じか少し深いところに多数発生していることは, 望月・ 他 (1985) も指摘している.

\section{3 地震波速度}

上節において，境界層が低ヤング率であることを明ら かにしたが，ここではより直接的にこの層の地震波速度 を調べる. 解析方法は, HuRUKAWA and Imoro (1987) の震源決定と速度決定を交互に繰り返す方法である. 彼 らはこの方法を用いて, 東海地域のサブクラスタル地震 は沈み込んだフィリピン海プレートの海洋性下部地款 $\left(V_{\mathrm{p}}=6.9 \sim 7.0, V_{\mathrm{s}}=4.0 \mathrm{~km} / \mathrm{s}\right)$ で発生していることを明 らかにしている，ただし，ここでは震源決定および観測 点補正値の計算には改良連係震源決定法を用い, 計算手 続きを簡潔にした，解析には，地震数がもっとも多く， かつ震源域が広い千葉地域で, $95 \leqq x \leqq 111 \mathrm{~km}, 6 \leqq y \leqq$ $22 \mathrm{~km}, 68 \leqq z \leqq 76 \mathrm{~km}$ の範囲に発生した地震 224 個を 用いた (Fig. 12 参照). 速度構造は水平成層構造とし, Table 1 の第 4 層を 2 分割し, 第 4 層の厚さを $37 \mathrm{~km}$, すなわち第 5 層までの深さを $67 \mathrm{~km}$ とし，地震が発生 している第 5 層 (半無限) の速度をV 5 とした. V5を $5.0 \mathrm{~km} / \mathrm{s}$ から $9.0 \mathrm{~km} / \mathrm{s}$ まで変えて, それぞれの速度モ デルに対してまず近くの観測点を用いて震源を決定す る. 次にこの決定された震源を仮定し，震源決定に用い ていない遠くの観測点を使って震源域の地震波速度を計 算した。計算は観測点ごとに行なう。速度計算に用いた 観測点は, 解析域の中心から $120 \mathrm{~km}$ 以遠で，かつ観測 地震数 10 以上のものであり，用いた読取値はランク $\mathrm{A}$ のみである.なお，計算時に走時残差が標隼偏差の 2 倍 をこえる読取值は逐次取り除いた。計算の結果, 仮定し た速度 $V 5$ と計算速度 $V$ が一致するとき, 仮定が正し かったことになり，速度が求まる．Fig. 15 に結果を示 す. 図には決定速度の標準誤差が $0.4 \mathrm{~km} / \mathrm{s}$ 以下の観测 点の平均値とその標準偏差を，震源決定の時に仮定した 速度 V5 に対して示す．用いた観測点数は 12〜18 点で ある. 両者は $V=5.0 \mathrm{~km}$ と $V=7.5 \mathrm{~km} / \mathrm{s}$ のとき完全に 一致するが, $V \leqq 7.5 \mathrm{~km} / \mathrm{s}$ では常にほぼ一致している. 一方, $V \geqq 8.0 \mathrm{~km} / \mathrm{s}$ では $V$ は明らかに $V 5$ よりも小さ くなっている，以上から，速度を求めることはできな かったが, 逆断層型地震は海洋性マントル等の高速度層 では発生していないと言うことはでき，上節の応力分布 からの推定と矛盾しない.

なお，震源域の地震波速度が小さくなるほど震源の深 さ方向の広がりが大きくなる. たとえば， $V 5=5.0 \mathrm{~km} /$ 


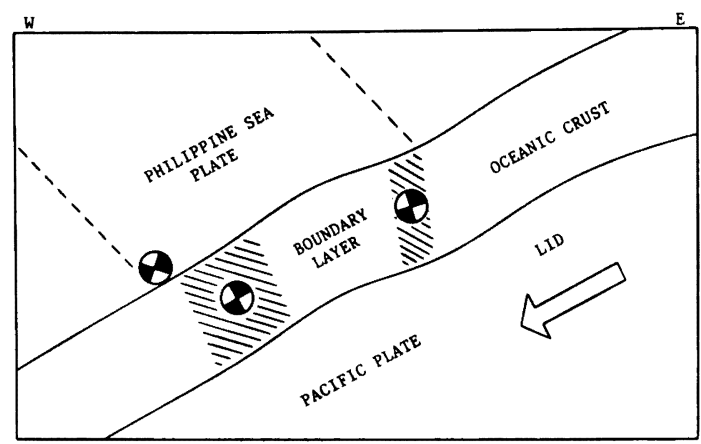

Fig. 16. A schematic figure of the boundary layer between the Pacific and Philippine Sea plates beneath the southwestern Ibaraki and the Chiba prefectures. Shaded areas represent hypocental areas of thrust earthquakes of which mechanism diagrams are shown onto a vertical plane. Normal earthquakes occurring at the western edge of the boundary layer are also represented by a mechanism diagram.

$\mathrm{s}$ のときの境界層の厚さは, $V 5=7.8 \mathrm{~km} / \mathrm{s}$ のときの 2 倍になる，それゆえ，正しい厚さを求めるには，境界層 内の地震波速度を正確にみつもる必要がある.

\section{4 起源}

両プレート境界の低弾性率の境界層としては沈み込ん だ海洋性地款が考えられる．既に述べたように，境界層 の厚さは約 $4 \mathrm{~km}$ である.この値は, LuDwig et al. (1966) と DEN et al. (1971) が東北・北海道冲において 求めた, 日本海溝・千島海溝に沈み込む直前の海洋性地 款第 1 ・第 2 層（P 波速度： $V_{\mathrm{p}}=2 \sim 5 \mathrm{~km} / \mathrm{s}$ ）の厚さ 2 $\mathrm{km}$ よりは厚く、海洋性地壳第 3 層 $\left(V_{\mathrm{p}}=6.6 \mathrm{~km} / \mathrm{s}\right)$ の 厚さ $5.3 \mathrm{~km}$ ないし $6.4 \mathrm{~km}$ よりは薄い. IWASAKI et al. (1989) は海底地震計による人工地震観測記録を波線追 跡法により解析し, 北海道南東沖の千島海溝周辺の地 殻・最上部マントル構造を求めた. それによると, 厚さ 2〜3 km の太平洋プレート最上部の海洋性地款第 2 層 $\left(V_{\mathrm{p}}=3.8 \sim 6.5 \mathrm{~km} / \mathrm{s}\right)$ は, 厚さ $4 \sim 5 \mathrm{~km}$ の海洋性地款 第 3 層（ $V_{\mathrm{p}}=6.5 \sim 7.0 \mathrm{~km} / \mathrm{s} ）$ ととむに千島海溝から沈 み込んだ後も，そのまま深さ $25 \mathrm{~km}$ まで沈み込み続け ている. 彼らの求めたのは深さ $25 \mathrm{~km}$ 程度までであり, ここで解析した地震の深さ 65〜85 km までそのまま延 長できるかどうかはわからないが, 可能性は十分ある.

それでは，境界層は海洋性地款のどの部分に対応する のだろうか. 上部地殼の厚さは上記 3 例では, 2 3 km であり，境界層の厚さ約 $4 \mathrm{~km}$ よりあかなり薄い. しか も, 前項 5.3 で述べたように地震波速度が小さいと境界 層が厚くなり，上に述べた値とはますます一致しなくな
る. 一方, 下部地殼の厚さは $4 \sim 6 \mathrm{~km}$, 地款全体の厚さ は 7〜8 km となり，いずれも低地震波速度を考虑した 境界層の厚さによく一致する，それゆえ，境界層の起源 は沈み込んだ海洋性地款全体ないし海洋性下部地款であ ると思われる。しかし, 境界層の地票波速度構造がか らない現時点では、単に境界層の起源は沈み込んだ海洋 性地款であると結論すべきであろう.

海洋性地款がプレートの一部として上部マントル中に 沈み込んでいることは, 既にいくつかの地域で明らかに されている [まとめは松沢 (1989)]. 例えば, 東海から近 畿地方にかけては, フィリピン海プレートの沈み込みに ともなって, サブクラスタル地震が発生しており, 走時 および波形解析から少なくとも深さ 50 ～ $60 \mathrm{~km}$ までは 地震波速度 $V_{\mathrm{p}}=7 \mathrm{~km} / \mathrm{s}, V_{\mathrm{s}}=4 \mathrm{~km} / \mathrm{s}$ の海洋性下部地殼 （海洋性地殼第 3 層）が沈み込み，その内部で張力軸が プレートの走向に平行な地震が発生している[例えば Hori et al. (1985), HURUKAWA and IMOTo (1987)]. こ の例のように, 地震波速度が求められている場合は，す なわち内部で地震が発生しているところでは，海洋性下 部地款が沈み込んでいることが明らかにされている［松 沢 (1989)]. しかし今回発見したような，内部でプレー トのスリップ・ベクトルに平行な王縮軸をもつ逆断首型 地震が発生している境界層については、これまでのとこ ろ報告はない.

OBARA and SATo (1988) と OBARA (1989)は関東地方 に沈み込む太平洋プレート上面に $\mathrm{S}$ 波が強く反射する 反射面が存在することを反射 S 波の走時解析から見い だした，彼らは反射波の継続時間と高い反射係数から， 反射面は表面が粗く，数 $\mathrm{km}$ の厚さをもち，インピーダ ンス比が大きいと考えた. OBARA (1989) によると、こ の反射面は地震活動から求めた太平洋プレート上面の傾 斜・走向ともよく一致し，深さ 60 から $120 \mathrm{~km}$ の範囲 に位置する. 我々が見つけた境界層は彼の反射面存在域 のちょうど東端に位置し, 反射面の性質のみならず, 深 さ・傾斜・走向ともよく一致することから，これらは同 一物だと考えられる.

以上, 太平洋・フィリピン海両プレート境界に存在す る，西下がり低角節面をむつ逆断層型地震を発生させる 境界層の性質について調べてきたが，Fig. 16 に模式図 を示す。ただし，境界層の形状・地震発生場所は場所に より多少異なる.

\section{§ 6. 1985 年 10 月 4 日の茨城千葉県境地震 (M6.1)}

本震直後 3 日間の震央分布を Fig. 17 に示す. 本図か ら, 断首面は南北約 $5 \mathrm{~km}$, 深さ方向約 $4 \mathrm{~km}$ の南北走向 鈶直であり，破壊が北から南へ，浅部から深部へ進行し 


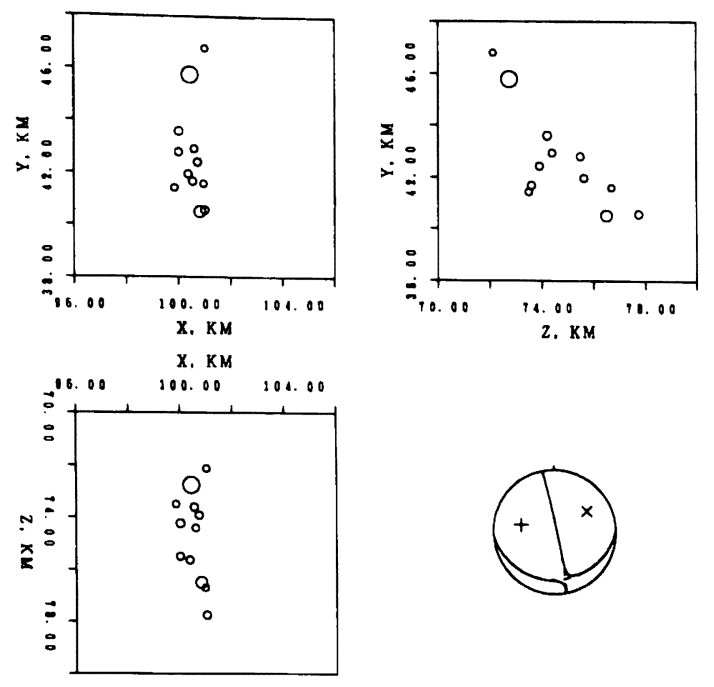

Fig. 17. Relocated hypocenters of the 1985 Ibaraki-Chiba Border earthquakes. The main shock $(M 6.1)$ and it's aftershocks within 3 days are shown. Equal-area projection of the geometrical representation of the moment tensor solution (after Dziewonski et al., 1986) of the main shock is also shown. The compression and tension axes are indicated by a plus and by a cross, respective1y. This figure indicates that the fault plane of this earthquake is nearly vertical.

たことがわかる.この面は Fig. 9 に示す本震 (No. 2) の 発震機構解の一節面（南北走向で西上がり東落ち）に非 常によく一致する. また Fig. 17 には参考のために DzIEwonski et al. (1986)の CMT 解も示す. この発震機 構は既に述べたように, フィリピン海プレートと太平洋 プレートの相対運動によって境界層内で発生している他 の地震のメカニズムとはまったく異なる. Figs. 9,14 か らも明らかなように, この地震の震源が境界層で発生す る地震よりあ明らかに深いことから、これは太平洋プ レート内部（地殼よりもヤング率が大きいマントル領 域)で発生した地震と思われる. それでは, なぜこの地 域だけこのような特異な地震が発生したのだろうか。 そ れは，この地震の震源の上での両プレートのカップリン グが周辺地域よりも強くて, プレート境界層の地縟が発 生せずに, 太平洋プレート内部の東西圧縮応力が強くて 破壊が起こったためだと思われる.これについては, 次 節で議論する。

なお，本地震を解析した堀 (1986)は，この地震の断層 面をほほ東西走向, 南へ傾斜する面と考え, プレートの 沈み込む量の南北での食い違いによるプレート内部の地 票と考えた。しかしこの考えは Fig. 17 の䟴源分布図か
ら明らかなように，断層面を取り違えており，間違って いると思われる. 彼が震源再決定しながら断層面の選択 を誤ったのは，用いた観測点補正值が正しくなかったた めであろう. 彼の値と我々の値では最大 0.7 秒 (IWT 観 測点）異なる. そのため大きい地震と小さい地祳で震源 が系統的にずれたのである，大きい地震だけに注目すれ ば，彼の図 (Fig. 3) からでも南北走向の節面を断層面と みなせるだろう。このことは Fig. 8 からも明らかであ る. 震央分布図あるいは東西断面図をみれば，ルーチン 震源では明らかに小さい地票は大きい地震の東側に分布 している，しかしここで用いた改良連係震源決定法で再 決定した震源の位置は地震の大きさに依存しない。

§7. 太平洋・フィリピン海プレートのカップリング

Fig. 14 に示したように, 西下がり低角節面をもつ逆 断層型地震の地震帯の西端は, ちょうど 1985 年茨城千 葉県境地震 (M6.1) が発生した D で, もっとも東に引っ 込んでいる，そしてこの地震の震央域の南北と東で両プ レートが滑り（すなわち，境界層内部が变形し）, 震央の 直上では滑っていない（すなわち，カップリングが非常 に強く，境界層内部が変形しない）。これがこの太平洋プ レート内部に応力が集中し，この地震が発生した原因で ある.

次にその他の，境界層外で発生した地震をみてみる.

Fig. 14 には，逆断層型地震発生域外で発生した，1985 年茨城千葉県境地震に関連した地震以外の地震につい て, 張力軸を実線で示した. A, C, E の各地域ではいずれ 6逆断層型地震発生域西端のすぐ外側で東北東〜西南西 ないし北東〜南西方向に張力軸をすつ正断層型地震が発 生している.このうち $\mathrm{A}, \mathrm{C}$ 地域では, 西下がりの境界層 の延長よりも少し浅い側に起こり，張力軸がほぼ南北な いし南南東〜北北西に走る地震帯にほぼ直交している. このことから，これらの地祳は，境界層端の応力集中に よりフィリピン海プレート内部で発生した正断層型地震 であると思われる。このことは，これらの地震発生場所 では，両プレートのカップリングが，すなわち境界層内 部の強度が，地震帯内部よりも強いことを示唆してい る.

$\mathrm{E}$ の西端の正断層型地縟は, 張力軸が地震帯に平行な 北北東〜南南西でかつ震源はすぐ東の地磦群の地震面の 延長よりも深く，A，C とは少し違う。茨城千葉県境地震 の震源域上での両プレート境界でのカップリングが強い 之, 本地震の発生場所では太平洋プレート内部に茨城干 葉県境地震の方向が張力軸になる応力場が生じることか ら（なぜなら、フィリピン海プレートを固定して考える と、茨城千葉県境地震の震源域はその場に留まろうとす 
るのに対して、本地震の震源域は西へ沈み込んでいくた め),これは太平洋プレート内部の地震であると思われ る.

一方, 地震帯の東側には，地震帯の延長よりも5〜10 $\mathrm{km}$ 浅いところで西北西〜東南東ないし北北西〜南南東 張力軸の地震が $\mathrm{E}$ と F 地域で 3 個発生している. 張力 軸の向きがほぼ茨城千葉県境地震の方向に向いているこ とから, 茨城千葉県境地震の震源域上での両プレートの カップリングが強いために生じたフィリピン海プレート 内部の地震と考えることも可能である（なぜなら、太平 洋プレートを固定して考えると、茨城千葉県境地震の震 源域はその場に留まろうとするのに対して、本地震の震 源域は東へ進んでいくため).

以上ここにあげたすへてての地震は，逆断層型地震発生 域の低カップリングと, 茨城千葉県境地震震源域上での 強カップリングで説明できる. 屯ちろん，これは可能な メカニズムの一つであり, これらの地震の発生理由を正 しく明らかにするには，むう少し広い範囲の地震活動之 発震機構を調へろ必要がある.

川崎・松田 (1987) は，筑波・千葉地震帯における太 平洋・フィリピン海両プレート間のサイスミック・カッ プリングを調べた，彼らは筑波・千葉地震帯内の 4 つの 地磦の巣における最近 18 年間のサイスミック・カップ リングが $0.1 \sim 0.2$ 程度と “普通程度”であるとしてい る. なお, 地震が発生していない場所も含めた筑波・千 葉地票帯全体を考えれば, この值は 3 分の 1 になり, カップリングは更に小さくなる.このようにサイスミッ ク・カップリングが小さいことは, 両プレート間に低弾 性率の境界層が存在し, その内部で逆断層型地震が発生 することと調和的である.

\section{§8. 結 論}

1. 連係震源決定法を改良した。すなわち，観測点補 正値が震央域の中心から測った震央距離および観測点方

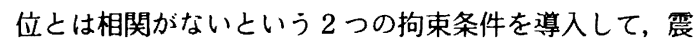
源決定の安定化をはかった。

2. 上記, 改良連係震源決定法を用いて, 茨城県南西 部筑波側から千葉県中部にかけての「筑波・千葉地震 帯」に発生する深さ 50 ～80 km の地震の震源 822 個を 再決定するとともに, 主な地震 75 個の発震機構を求め た.

3. 大多数の地震は平均 $30^{\circ}$ の傾斜角で, 東から西へ 沈み込む太平洋プレートと, 西から沈み込んだフィリピ ン海プレート先端部との境界で発生した西下がりの低角 節面をもつ逆断層型地震である.この境界は厚さ約 4 $\mathrm{km}$ の層であり，沈み込んだ太平洋プレート最上部に存
在する低速度・低弾性率の海洋性地殼であると思われ る.

4. 上記, 境界層に発生する地震はすべて西下がり低 角節面をむつ逆断層型地票であるが, 震源分布をみると その断層面は必ずしも西下がりの低角節面ではなく, 東 下がりの高角節面であることが多い.

5. 境界首の存在範囲は南北約 $90 \mathrm{~km}$, 東西 7 16 $\mathrm{km}$ である. 境界層の形状は南北で少し異なる. 大ざっ ぱにいって, 北側ではほぼ真西に約 $25^{\circ}$ で傾斜し, 南側 では $\mathrm{W} 13^{\circ} \mathrm{S}$ の方向に約 $30^{\circ}$ の傾きで傾斜する. 更に細 かくみると, 境界層の傾斜角は場所により異なり, 東側 で小さく $\left(5^{\circ} \sim 17^{\circ}\right)$, 西側で大きい $\left(19^{\circ} \sim 35^{\circ}\right)$.

6. 地震活動のもっとも高い千葉県中部では, 上記逆 断層型地震の他に, 北西〜南東張力軸の正断層型地震か フィリピン海プレート内部と, 太平洋プレート内部（マ ントル領域) で発生している.

7. 1985 年 10 月 4 日に発生した茨城千葉県境地縟 $(M 6.1)$ の断層面は東落ちの南北走向鉛直の面で, 破壊は 北端浅部から南へ進行した。この地震は, この地震の祳 源域の上でのフィリピン海プレートと太平洋プレートの カップリングが非常に強いために発生した太平洋プレー 卜内部の地震である.

8. 逆断層型地震発生域の外で発生した地票の発震機 構は, 上記茨城千葉県境地震の震源域の上での両プレー トのカップリングが強いことから生じる応力場で説明で きる。

\section{謝辞}

地震活動の調査にはSEIS-PC［石川(1986)］を用い た. 查読者の意見は原稿の改善に役立ちました。

\section{文献}

Den, N., H. Hotta, S. Asano, T. Yoshi, N. SakajiRi, Y. Ichinose, M. Motoyama, K. Kakilchi, A. F. BeresNEv and A. A. Sagalevitch, 1971, Seismic refraction and reflection measurements around Hokkaido. Part 1. Crustal structure of the continental slope off Tokachi, J. Phys. Earth, 19, 329-345.

DEWEY, J. W., 1972, Seismicity and tectonics of western Venezuela, Bull. Seism. Soc. Am., 62, 17111751.

Douglas, A., 1967, Joint Epicentre Determination, Nature, 215, 47-48.

Dziewonski, A. M., J. E. Franzen and J. H. WoodhouSE, 1986, Centroid-moment tensor solutions for October-Decemcer 1985, Phys. Earth Planet. Interiors, 43, 185-195.

FreEdMan, H. W., 1967, A Statistical Discussion of $P$ Residuals from Explosions, Part II, Bull. Seism. Soc. 
Am., 57, 545-561.

浜田和郎 - 大竹政和 - 岡田義光 - 松村正三 - 山水史生 $\cdot$ 佐藤春夫 - 井元政二郎・立川真理子・大久保正 - 山本 英二・石田瑞穂・笠原敬司・勝山 $コ$ シ子・高橋 博, 1982, 関東 - 東海地域地殸活動観測網一国立防災科 学技術センター一, 地震 2, 35, 401-426.

橋本 学, 1981, 西南日本に沈み込むフィリピン海プ レートの形状と三次元応力分布 (第 2 報), 地震 2,34 , 197-211.

堀貞喜, 1986,1985 年 10 月 4 日干葉・茨城県境付近 に発生した地震の発生メカニズムとその構造的意義に ついて, 地震 2,39, 457-468.

Hori, S., H. Inoue, Y. Fukao and M. Ukawa, 1985, Seismic detection of the untransformed 'basaltic' oceanic crust subducting into the mantle, Geophys. J. Roy. Astr. Soc., 83, 169-197.

Hurukaw A, N. and M. Імото, 1987, P and S velocities in the source region of subcrustal earthquakes in the Tokai district, central Japan, J. Phys. Earth, 35, 1-17.

井元政二郎， 1984，関東・東海地域における起震応力 場, 国立防災科学技術センタ一研究速報，66，1-76.

井元政二郎, 1985, 関東南部におけるフィリピン海プ レート内の応力場, 月刊地球, 7, 93-96.

石田瑞穂, 1986, 関東・東海地域の震源分布から推定し たフィリピン海及び太平洋プレートの等深線, 国立防 災科学技術センター研究報告, 36,1-19.

石川有三, 1986, SEIS-PC 改訂版の概要, 情報地質, 11 , 65-74.

Iwasaki, T., H. Shiobara, A. Nishizawa, T. Kanazawa, K. Suyehiro, N. Hirata, T. Urabe and H. Shimamura, 1989, A detailed subduction structure in the Kuril trench deduced from ocean bottom seismographic refraction studies, Tectonophysics, 165, 315-336.

笠原敬司, 1985, プレートが三重会合する関東・東海地 方の地殼活動様式, 国立防災科学技術センタ一研究報 告, $35,33-137$.

川崎一朗・松田恵子, 1987, 南関東におけるプレート間 サイスミックカップリンと仮想東京直下地震, 地震 2 , 40, 7-18.

Ludwig, W. J., J. I. Ewing, M. Ewing, S. Murauchi, N. Den, S. Asano, H. Hotta, M. Hayakawa, T. AsaNUMA, K. ICHIK A W A and I. NoGUCHI, 1966, Sediments and structure of the Japan trench, J. Geophys. Res., 71, 2121-2137.
MAKı, T., 1984, Focal mechanisms and spatial distribution of subcrustal earthquakes occurring in clusters beneath the Kanto district, Bull. Earthq. Res. Inst., 59, 127-196.

Maki, T., I. KawASAKI and A. Horie, 1980, Earthquake mechanisms associated with the conjunction of the sinking plates beneath the Kanto district, Japan, Bull. Earthq. Res. Inst., 55, 577-600.

松澤 暢, 1989, 後続波から推定される沈み込むプレー 卜境界の地震波速度構造, 地震 2, 42, 525-536.

Minster, J. B. and T. H. Jordan, 1978, Present day plate motion, J. Geophys. Res., 83, 5331-5354.

Minster, J. B. and T. H. JoRdan, 1979, Rotation vectors for the Philippine and Rivera plates, EOS Trans. Am. Geophys. Union, 60, 958.

Minster, J.B., T. H. Jordan, P. Molnar, and E. HAINES, 1974, Numerical modelling of instantaneous plate tectonics, Geophys. J. Roy. Astr. Soc., 36, 541-576.

望月英志 - 佐久間喜代志 - 井元政二郎, 1985, 関東 - 東 海地方の地震の発震機構 (1979-1983), 地震 2, 38, 411-422.

中村一明・島崎邦彦, 1981, 相模・駿河卜ラフとプレー トの沈み込み、科学, 51, 490-498.

ObarA, K., 1989, Regional extent of the S wave reflector beneath the Kanto district, Japan, Geophys. Res. Lett., 16, 839-842.

Obara. K. and H. Sato, 1988, Existence of an S wave reflector near the upper plane of the double seismic zone beneath the southern Kanto district, Japan, J. Geophys. Res., 93, 15037-15045.

大竹政和・笠原敬司, 1983, 茨城県南西部に見られるぺ 了地震, 地震 2, 36, 643-653.

OKADA, Y. and K. KaSAhara, 1990, Earthquake of 1987, off Chiba, central Japan and possible triggering of eastern Tokyo earthquake of 1988, Tectonophysics, 172, 351-364.

SENo, T., 1977, The instantaneous rotation vector of the Philippine Sea plate relative to the Eurasian plate, Tectonophysics, 42, 209-226.

SomervilLE, P., 1980, Earthquake mechanisms at the head of the Philippine Sea plate beneath the southern Kanto district, Japan, J. Phys. Earth, 28, 293308. 